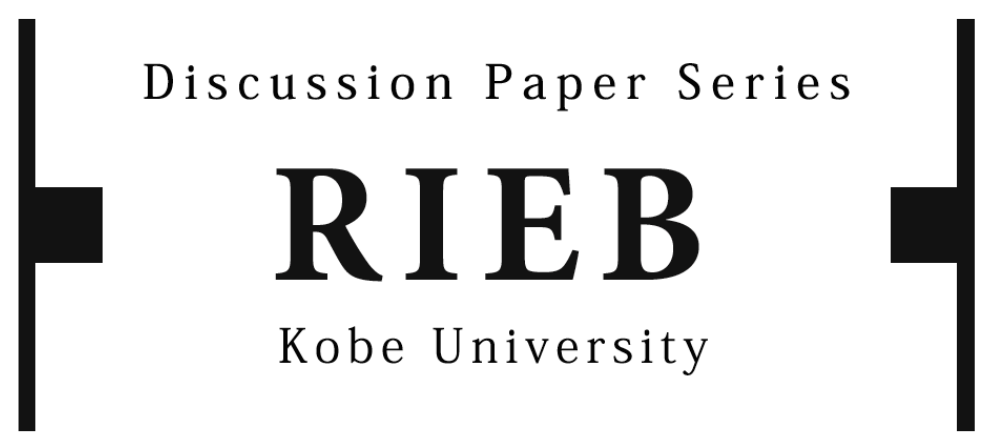

DP2018-12

Effects of Corporate Governance on the Relationship between Accounting Quality and Trade Credit: Evidence from Japan

Masahiro ENOMOTO

Revised September 13, 2022

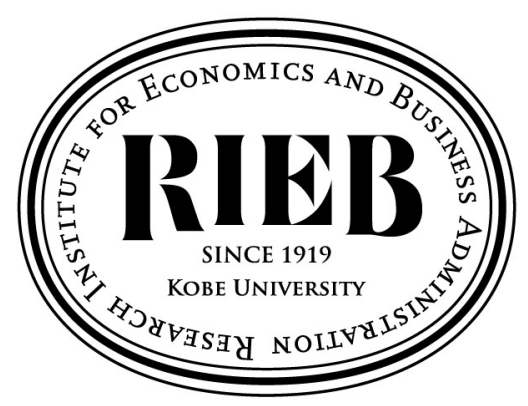

Research Institute for Economics and Business Administration Kobe University 


\title{
Effects of Corporate Governance on the Relationship between Accounting Quality and Trade Credit: Evidence from Japan
}

\author{
Masahiro Enomoto
}

Kobe University

I acknowledge and appreciate the helpful comments from Nobuhiro Asano, Keishi Fujiyama, Shu Inoue, Fumihiko Kimura, Yuya Koga, Kenji Kometani, Yoshitaka Ohashi, Ruei-Shian Wu, Tomoyasu Yamaguchi, Yuto Yoshinaga, and workshop participants at Tohoku University Accounting School (Tohoku University Accounting School Workshop) and 2018 Taiwan Accounting Association Annual Conference and Asian Accounting Associations Conference.

Masahiro Enomoto, Kobe University, Research Institute for Economics and Business Administration, 2-1 Rokkodai, Nada, Kobe 657-8501 JAPAN

Phone: +81 78803 7031; Email: menomoto@rieb.kobe-u.ac.jp 


\title{
Effects of Corporate Governance on the Relationship between Accounting Quality and Trade Credit: Evidence from Japan
}

\begin{abstract}
This study investigates the effects of shareholdings on the relationship between accounting quality and trade credit in Japan. It focuses on cross- and stable shareholdings, which are well-known features of Japanese corporate governance, as a private information-sharing system. The relationships between cross- and stable shareholdings, accounting quality, and trade credit are tested. The results show that the trade credit of customers without either cross- or stable shareholdings increases with accounting quality, and in most cases, such shareholdings weaken the relationship between accounting quality and trade credit. These findings suggest that close ties to cross- and stable shareholders reduce the importance of accounting information through sharing private information.
\end{abstract}

Keywords: trade credit; accounting quality; cross-shareholdings; stable shareholdings JEL Classifications: G34; M41

Data Availability: Data are available from sources indicated in the text.

\section{INTRODUCTION}

Trade credit is a major source of short-term financing for firms in several countries. For example, $\mathrm{Li}, \mathrm{Ng}$, and Saffer (2021) show a ratio of trade credit to cost of goods sold that is, on average, 26.4 percent in an International Financial Reporting Standards (IFRS) sample of 36,180 firm-years from 30 countries between 2000-2014, and 22.4 percent in a non-IFRS sample using 36,227 firm-years across six countries. ${ }^{1}$ Chen, Liu, Ma, and Martin (2017) report an average ratio of trade credit to total assets of 11 percent among a sample of US firms. Business transactions using trade credit are also prevalent in Japan. In this study's sample, the ratio of trade credit to total assets is 14 percent on average, which is considerably higher than the both 10 percent for short-term borrowings and 7 percent for long-term borrowings. El Ghoul and Zheng (2016) report that the receivables

\footnotetext{
${ }^{1}$ Levine, Lin, and Xie (2018) show an average ratio of trade credit to total debt liabilities of 25 percent using over 3,500 firms across 34 countries from 1990 to 2011.
} 
to sales ratio of Japanese firms ranks eighth out of 49 sampled countries in their international comparative study. Trade credit in Japan is characterized by long maturity and low interest rates, and is therefore similar in nature to short-term borrowings because of the "promissory bill" system used in Asian countries (Lau and Shaede 2020; Miwa and Ramseyer 2008; Uchida, Uesugi, and Hotei 2010). ${ }^{2}$ Given its economic importance, accounting information and its quality should play an important role in offering trade credit. However, prior studies have not reached a consensus on the relationship between accounting quality and trade credit, possibly because business practices for trade credit differ by country. This study examines this relationship in Japan, focusing on whether Japanese corporate governance as a private information channel changes the role of accounting information and abovementioned relationship.

Japanese corporate governance is characterized by close ties to stakeholders, such as cross- and stable shareholdings. This relationship with stakeholders results in exchanges of private information and affects the materiality of accounting information. It also offers an interesting avenue for research on the relationship between accounting quality and trade credit from the viewpoint of sharing private information. Japan is characterized by stakeholder corporate governance under code law and has the thirdlargest stock market worldwide. In code-law countries, major groups such as banks, business associations, and labor unions form a firm's agents, and insider communication between managers and stakeholders tends to be the primary system for resolving information asymmetry (Ball, Kothari, and Robin 2000). This means that communication with stakeholders adds another private information channel in the supplier-customer relationship. This impact of private information on the relationship between trade credit and accounting information has not been addressed in previous research. This study

\footnotetext{
2 " $\mathrm{T}(\mathrm{t}) \mathrm{he}$ buyer issues, and the seller receives, a bill after an invoice is issued. At or after the due date of the bill, the seller deposits the bill at a bank, the bank takes the bill to a regional clearinghouse (which is run by banks and is open every business day), and the bill is settled and cleared through the bank settlement system. ... The maturity of promissory bill is long" (Uchida et al. 2010, 7). The detail on promissory bills is described in Uchida et al. (2010) and Lau and Shaede (2020).
} 
serves as a basis for future research on trade credit and private information channels in Japan and countries with similar corporate governance.

Previous studies indicate that high-quality accounting information mitigates information asymmetry and reduces agency costs. These studies further show that debt and equity providers tend to offer financing to firms with high-quality accounting information, thereby allowing these firms to obtain favorable contract terms (e.g., Bharath, Sunder, and Sunder 2008; Francis, LaFond, Olsson, and Schipper 2004, 2005; Ge and Kim 2014; Hasan, Park, and Wu 2012; Lambert, Leuz, and Verrecchia 2007). However, few studies examine the association between accounting information and trade credit financing; thus, the relationship remains unclear. For example, Garcia-Teruel, MartínezSolano, and Sanchez-Ballesta (2014) demonstrate the positive relationship between accounting quality and trade credit among non-listed Spanish firms. Elemes and Filip (2022) report a similar relationship for private firms in five European countries. However, Chen et al. (2017) report negative relationships among listed US firms. The present study extends previous research by examining how a corporate governance structure that leads to private information sharing affects the impact of accounting quality on trade credit.

This study focuses on cross- and stable shareholdings as factors that influence the relationship between trade credit and accounting quality. Previous literature considers cross- and stable shareholdings (and main banks), which are well-known features of Japanese corporate governance (e.g., Aoki, Jackson, and Miyajima 2007; Aoki and Patrick 1994; Hoshi and Kashyap 2001). ${ }^{3}$ Cross-shareholders reciprocally hold each other's shares and rarely trade them. Many Japanese firms have transactional relationships with cross-shareholders, including suppliers, customers, and banks. In addition, firms and banks hold (albeit not reciprocally) shares of other firms with whom

\footnotetext{
3 The influence of cross- and stable shareholdings in Japan is said to have weakened around the mid-1990s. However, in Miyajima and Kuroki's (2007) sample, the ratio of cross- and stable shareholdings stabilize after around 2005. In this study's sample, the ratio also levels off after around 2005.
} 
they have long-standing business relationships. ${ }^{4}$ They form stable shareholders with cross-shareholders (Sheard 1994) and play a similar role for managers as crossshareholders do (Ikeda, Inoue, and Watanabe 2018, 56). ${ }^{5}$ Therefore, in this study. crossand stable shareholders are assumed to have similar effects on the relationship between accounting quality and trade credit, and shares held by stable shareholders are defined as stable shareholdings. In most cases, stable shareholders act as friendly shareholders for incumbent managers, although they do not necessarily offer as much protection as crossshareholders (Ikeda, Inoue, and Watanabe 2018, 56).

Cross- and stable shareholders play crucial roles in Japanese corporate and industrial groups known as keiretsu, and in business economies. Cross and stable shareholders can be viewed as friendly or sympathetic by allowing managers to protect themselves from the external takeover market. Moreover, they principally comprise longterm transaction partners (including financial institutions) (Sheard 1989, 409).

Cross- and stable shareholders regularly collect private information to facilitate transactions in these relationships. When private information is shared, accounting information tends to play a lesser role within cross-shareholding groups. Previous literature demonstrates that the private information often exchanged between firms and stakeholders reduces the role of accounting information (e.g., Ball and Shivakumar 2005; Beatty, Liao, and Weber 2010; Biddle and Hilary 2006). Biddle and Hilary (2006) argue that bank financing and keiretsu, as important sources of financing, could serve as private channels to reduce information asymmetry in Japan. Although their study suggests that Japanese corporate governance reduces the importance of accounting information through its relationship, they did not test this reduction directly.

Several studies argue that private information exchanged between managers and cross-shareholders spreads to outside investors (e.g., Bae and Kim 1998; Jiang and Kim

\footnotetext{
4 This type of shareholding is referred to as "other stable shareholdings."

5 This study posits that stable shareholders include cross-shareholders and other stable shareholders.
} 
2000). They present evidence that greater cross-shareholdings result in less information asymmetry in Japanese capital markets, and claim that private information is more prevalent in firms with higher rather than lower cross-shareholdings. Based on this prior research, the present study posits that cross-shareholdings could reduce information asymmetry between firms and suppliers.

Given that the pervasiveness of private information in the relationship between firms and cross- and stable shareholders reduces the importance of accounting information, this study predicts that strong ties to cross- and stable shareholders weakens the effect of accounting quality on trade credit. In their studies, Garcia-Teruel et al. (2014) and Chen et al. (2017) did not investigate the effects that result from close ties to shareholders. The regression models in the present study are designed following Chen et al. (2017) and incorporate cross- and stable shareholdings. As a measure of accounting quality, I use the first principal component score of three accrual-based metrics derived using principal component analysis, according to prior literature (Bharath et al. 2008, Beatty et al. 2010, and Chen et al. 2017). Cross- and stable shareholders are taken from the NRL (NLI Research Institute) database.

To examine the effects of cross- and stable shareholdings on the relationship between accounting quality and trade credit, I collect 27,794 firm-years from Japanese firms between 2001-2016 from Nikkei NEEDS-FinacialQUEST. I investigate the incremental effect of accounting quality on trade credit with stable shareholdings compared to the effect on firms without stable shareholders.

This study finds that the trade credit of firms without stable shareholdings increases with accounting quality. Suppliers are more likely to consider accounting quality in the absence of stable shareholders. Further, stable shareholdings reduce the effect of accounting quality on trade credit, consistent with this study's prediction. When splitting stable shareholdings into cross- and other stable shareholdings, crossshareholdings generally have a similar effect on the association. Cross- and stable 
shareholdings are positively associated with trade credit, indicating that customers in the same business group as suppliers can receive more trade credit. In additional tests, crossand stable shareholdings are replaced with bank shareholding variables (banks' and main banks' shareholdings and cross-shareholdings by banks). This is because banks are the center of keiretsu and play a key role in obtaining private information from crossshareholders. Bank shareholding variables have a similar effect on the abovementioned association.

This study makes three contributions to the literature. First, to the best of my knowledge, this study is the first to indicate that a close tie to shareholders (i.e., are crossand stable shareholdings) weakens the relationship between accounting quality and trade credit financing in proportion to the cross- and stable shareholding ratio. Previous studies on accounting quality and trade credit only discuss the exchange of private information through business relationships between customers and suppliers. Thus, the impact of private information exchange with stakeholders on the materiality of accounting information has not yet been addressed. This study extends the literature on the substitution of private information for accounting information by focusing on trade credit. The ratio of cross- and stable shareholdings declined between the mid-1990s and mid2000 s, which may have increased the importance of accounting information relative to trade credit.

Second, the positive relationship between accounting quality and trade credit financing among firms without cross- and stable shareholdings complements previous studies that demonstrate the same relationship between accounting quality and debt and equity financing (e.g., Bharath et al. 2008; Francis et al. 2004, 2005). Considering the importance of trade credit in financing, the present study contributes to the growing body of literature on the relationship between accounting quality and financing.

Finally, the results for firms without stable shareholdings are consistent with those of Garcia-Teruel et al. (2014) based on a sample of Spanish private firms, but inconsistent 
with those of Chen et al. (2017) based on a sample of US listed firms. Japan and Spain are considered to share common code-law and bank-oriented financial systems, which differ from systems in the US. Garcia-Teruel et al. (2014) provide no interaction terms for accounting quality with bank variables under a bank-oriented financial system. In countries with similar corporate governance, my findings have implications for the relationship between borrowings, including trade credit, accounting quality, and the corporate governance system, which may weaken the function of accounting information in contractual relationships.

The remainder of this paper is organized as follows. Section 2 describes the institutional setting in Japan, literature review, and hypothesis development. Section 3 presents the study's research design, data, and sample-selection procedures. Section 4 reports the empirical results, while Section 5 reports on additional and robustness tests. Finally, Section 6 concludes the paper.

\section{LITERATURE REVIEW AND HYPOTHESIS DEVELOPMENT}

\section{Prior literature on the relationship between trade credit and accounting quality}

Previous studies show two conflicting hypotheses and sets of findings on the relationship between accounting quality and trade credit. Related studies (e.g., Francis et al. 2004, 2005; Bharath et al. 2008) indicate that high accounting quality lowers information risk, thereby reducing debt and capital costs. Therefore, suppliers offer more trade credit to customers with better accounting quality, providing customers with an incentive to improve accounting quality to receive more trade credit. Using a sample of 8,396 firmyears from Spanish private firms between 1995-2005, Garcia-Teruel et al. (2014) report that suppliers tend to provide more trade credit to firms with higher accrual quality. Elemes and Filip (2022) document a positive relationship between trade credit and accrual quality for 423,434 private firms in five European countries, and the results are promoted 
by information asymmetry and uncertainty regarding future cash flows. ${ }^{6}$

However, trade credit typically has higher interest rates than short-term debt, leading to an opposite relationship between accounting quality and trade credit. Previous research suggests that firms with higher accounting quality can finance short-term debt from financial institutions more easily and cheaply. If so, customers with low accounting quality would have difficulties accessing debt and equity financing and would need to increase trade credit because of their financial constraints. In this case, trade credit is negatively related to accounting quality. Chen et al. (2017) present evidence that accounting quality is negatively associated with trade credit, based on a US sample of 115,703 firm-years between 1985-2011.

Prior research shows that accounting quality has both positive and negative effects on trade credit amounts. In a general sense, financial information is used to facilitate transactions between suppliers and customers. More specifically, it is a major source of credit ratings on which suppliers usually rely to offer trade credit. Pike and Cheng (2001) reported that credit ratings are the most popular source of information on credit risk. Moreover, based on a survey of Japanese private firms, Uesugi et al. (2009) find that only 6.3 percent of trade credit contracts include early payment discounts. This tendency is similar to that of Spanish firms (Garcia-Teruel and Martınez-Solano 2010; Garcia-Teruel et al. 2014). Early payment discounts tend to be offered to risky customers (Klapper, Laeven, and Rajan 2012). The percentage (6.3 percent) in Uesugi et al. (2009) is much less than that of US firms in both $\mathrm{Ng}$, Smith, and Smith (1999) (24.5 percent), and Giannetti, Burkart, and Ellingsen (2011) (21.3 percent).

Trade credit in Japan tends to have long maturity and low interest rates with similar properties to short-term borrowing. This could lead suppliers in Japan to focus on

\footnotetext{
${ }^{6} \mathrm{Li}$ et al. (2021) assume that mandatory adoption of IFRS improves financial reporting transparency and find that IFRS adoption increases trade credit. Financial reporting transparency is a concept that closely relates to accounting quality as used in this study. Li et al. (2021) do not directly show the relationship between improved financial reporting transparency and increased trade credit.
} 
accounting quality when offering trade credit. Although the positive effect appears to dominate the negative effect, I do not propose a hypothesis regarding this relationship because neither effect can be eliminated. ${ }^{7}$

\section{Features of Japanese corporate governance and hypothesis development}

Several studies focus on cross- and stable shareholdings as characteristics of Japanese firms' corporate governance (e.g., Aoki and Patrick 1994; Hoshi and Kashyap 2001; Aoki et al. 2007). Cross-shareholders comprise suppliers, customers, and banks, and tend to rarely trade reciprocally held shares. Japanese industrial groups (keiretsu) typically involve extensive cross-shareholdings between two firms and between firms and banks (Berglof and Perotti 1994; Gilson and Roe 1993; Sheard 1994). Member firms actively and regularly engage in transactions with each other over the long term and strongly rely on trade credit financing within the group (Berglof and Perotti 1994). They typically share a strong network with suppliers and customers and often construct relationships through value or supply chains (e.g., Yoshikawa and Phan 2001). In addition to cross-shareholders, firms and banks hold stable shares of other firms within the business relationship. They form stable shareholder networks with cross-shareholders. Cross- and stable shareholdings protect firms from hostile takeovers and pressure from the capital market (Osano 1996; Sheard 1989, 1991). This system of interlocking shareholdings between firms stabilizes managerial positions.

In such an environment, managers can exchange private information within crossand stable shareholding groups, thereby alleviating information asymmetry. Specifically, information sharing comes through interlocking directorates and "presidential club" (Shacho-kai) meetings held regularly to exchange inside information on affiliated firms (Cooke 1996; Douthett and Jung 2001; Goto 1982; Sheard 1991). ${ }^{8}$ Through this

\footnotetext{
${ }^{7} \mathrm{Li}$ et al. (2021) also predict that the positive effect of accounting quality on trade credit is likely to outweigh the negative effect in a similar manner.

${ }^{8}$ Goto (1982) reports the coordination of R\&D within member firms. He also states that member firms
} 
mechanism, cross-shareholders can gain access to strategic information (e.g., associated firms' performance and business plans), develop strategic or business relationships, and provide mutual support (McGuire and Dow 2003, 2009). In Japan, cross-ownership of stock and access to information are particularly prevalent among firms in the same industrial group (keiretsu) (Jacobson and Aaker 1993, 403). Given that this type of information-sharing system lowers information asymmetry, cross- and stable shareholders may base decisions related to monitoring each other on inside information rather than accounting information. Therefore, assuming it is of the same volume and quality of accounting information, private information increases with stable shareholdings, while the impact of accounting information on trade credit should decreases. Private information is substituted for accounting information and its quality.

Studies have focused on the exchange of private and accounting information and its relationship with debtholders. Ball and Shivakumar (2005) compare conservatism between listed and non-listed firms, showing that private information tends to resolve information asymmetry and implies that private information substitutes accounting information between debtholders and the firm. Biddle and Hilary (2006) and Beatty et al. (2010) refer to debtholders as stakeholders that enhance the role of private information. Beatty et al. (2010) suggest that the role of accounting quality in investment efficiency becomes less important when external fund suppliers can access private information. Biddle and Hillary (2006) argue that firms with higher accounting quality invest more efficiently through better access to financing. However, in their international study, they fail to find such a relationship for Japanese firms, which they assert is because of bank financing and keiretsu, in which cross-shareholdings are crucial, as important sources of financing, could provide private channels to mitigate information asymmetry and reduce the importance of accounting information. Thus, their study also suggests that accounting information be substituted for private information in the relationship between debtholders

undertake various types of interfirm coordination. 
and firms. However, no previous studies investigate whether cross-shareholdings affect suppliers' trade credit offers. With communication of private information under crossshareholdings, such shareholdings could have a similar effect on suppliers included in the cross-shareholding group.

Regarding the information availability of firms with cross-shareholdings of external suppliers, it is useful to focus on the literature on the role of accounting information for market participants under Japanese corporate governance. Jacobson and Aaker (1993) provide evidence that Japanese capital markets have lower information asymmetry between managers and investors compared with those in the US. Bae and Kim (1998) and Jiang and Kim (2000) claim that cross-shareholding networks are influential in mitigating information asymmetry under Japanese corporate governance. Jiang and Kim (2000) report that stock prices for firms with higher cross-shareholdings incorporate more private information about future business prospects or strategies, concluding that more cross-corporate shareholdings lead to more information sharing or less information asymmetry between the firm and market participants (external investors). Considering the evidence for the positive effect of cross-shareholdings on the availability of private information in the Japanese stock market, and generally lower information asymmetry between firms and their suppliers than among market investors, I predict that external suppliers can (at least partly) rely on non-accounting information from firms with crossshareholdings to monitor customers. Further, information sharing through stable shareholdings can be explained in the same way as cross-shareholdings.

In summary, cross- and stable shareholdings in Japan encourage the exchange of private information, which reduces the role of accounting information. Accordingly, more cross- and stable shareholdings would weaken the effect of accounting quality on trade credit. Therefore, I formulate the following hypotheses:

\section{Hypothesis: Increases in cross- and stable shareholdings reduce the effect of}




\section{accounting quality on trade credit.}

Notably, suppliers can obtain private information through business relationships, and the amount of trade credit they offer to customers is likely to be based on private and public information. Suppliers may meet customers more regularly than banks to access information regarding business plans, industry and demand trends, $\mathrm{R} \& \mathrm{D}$, and financial information. Moreover, suppliers can know the size and timing of customer orders through daily operating activities (Miwa and Ramseyer 2008; Petersen and Rajan 1997; Uesugi et al. 2009). Access to customers' private information could make the relationship between accounting quality and trade credit ambiguous, thereby weakening it by imposing a bias. ${ }^{9}$ A supplier collects private information regardless of whether crossand stable shareholder relationships are present.

This study focuses on the effect of private information sharing on cross- and stable shareholdings, in addition to the above relationships.

\section{RESEARCH DESIGN, SAMPLE SELECTION PROCEDURE, AND DATA}

\section{Research design}

Equation (1) shows the baseline model tested in this study:

$$
\begin{aligned}
&\text { TradeCredit } \left._{i t}=\beta_{0}+\beta_{1} \text { AQ }_{i t-1}+\beta_{2} \text { LiquidCost }_{i t}+\beta_{3} \text { InfoAsym }_{i t}+\beta_{4} \text { Log }_{(\text {Asset }}\right)_{i t}+ \\
& \beta_{5} \log (\text { Age }+1)_{i t}+\beta_{6} \text { MktShare }_{i t}+\beta_{7} \text { POS_ChgSale }_{i t}+\beta_{8} \text { NEG_ChgSale }_{i t}+ \\
& \beta_{9} \text { ROA }_{i t}+\beta_{10} \text { MTB }_{i t}+\beta_{11} \text { AltmanZ }_{i t}+\beta_{12} \text { Leverage }_{i t}+\beta_{13} \text { CA }_{i t}+\beta_{14} \text { CL_Xtrade }_{i t}+ \\
& \beta_{15} \text { CashHold }_{i t}+\beta \text { INDUSTRY }+\beta \text { YEAR }+\varepsilon_{i t},
\end{aligned}
$$

where $A Q=$ accounting quality measure.

\footnotetext{
${ }^{9}$ Along with this argument, suppliers collecting private information weakens the relationship even when trade credit decreases with accounting quality. Specifically, an effect of private information on the relationship is also described in footnote 16 .
} 
The hypothesis is tested by running the regression model on equations (2) and (3):

TradeCredit $_{i t}=\beta_{0}+\beta_{1} A Q_{i t-1}+\beta_{2} A Q_{i t-1} \times$ StableSH $_{i t-1}+\beta_{3}$ StableSH $_{i t-1}+\beta_{4}$ LiquidCost $_{i t}+$

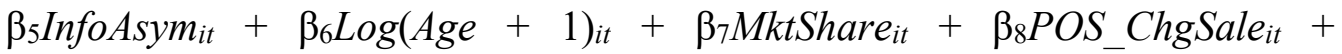
$\beta_{9} N E G_{-}$ChgSale $_{i t}+\beta_{10}$ ROA $_{\text {it }}+\beta_{11}$ MTB $_{i t}+\beta_{12}$ AltmanZ $_{i t}+\beta_{13}$ Leverage $_{i t}+$ $\beta_{14} C A_{i t}+\beta_{15} C L \_$Xtrade $_{i t}+\beta_{16}$ CashHold $_{i t}+\beta$ INDUSTRY $+\beta$ YEAR $+\varepsilon_{\mathrm{it}}$,

TradeCredit $_{i t}=\beta_{0}+\beta_{1} A Q_{i t-1}+\beta_{2} A Q_{i t-1} \times$ CrossSH $_{i t-1}+\beta_{3} A Q_{i t-1} \times$ OtherStableSH $_{i t-1}+\beta_{4}$ Cross SH $_{i t-1}+\beta_{5}$ OtherStableSH $_{i t-1}+\beta_{6}$ LiquidCost $_{i t}+\beta_{7}$ InfoAsym $_{i t}+\beta_{8} \log ($ Age $+1)_{i t}+\beta_{9}$ MktShare $_{i t}+\beta_{10}$ POS_ChgSale $i t+\beta_{11} N E G_{-}$ChgSale $i t+\beta_{12}$ ROA $_{i t}+$ $\beta_{13}$ MTB $_{i t}+\beta_{14}$ AltmanZ $_{i t}+\beta_{15}$ Leverage $_{i t}+\beta_{16}$ CAt $_{i t}+\beta_{17} C L_{-}$Xtrade $_{i t}+$ $\beta_{18}$ CashHold $_{i t}+\beta$ INDUSTRY $+\beta$ YEAR $+\varepsilon_{i t}$.

StableSH $=$ the sum of CrossSH and OtherStableSH,

CrossSH $=$ the ratio of shares mutually held by financial institutions and other business corporations, and

OtherStableSH $=$ the ratio of shares held by financial institutions, trust banks (for trading through their own accounts), and the parent company. ${ }^{10}$

The next approach, with a dummy variable for shareholdings, assesses the average effect of $A Q$ on trade credit under cross- and stable shareholdings:

TradeCredit $_{i t}=\beta_{0}+\beta_{1} A Q_{i t-1}+\beta_{2} A Q_{i t-1} \times$ StableSHD $_{i t-1}+\beta_{3}$ StableSHD $_{i t-1}+\beta_{4}$ LiquidCost $_{i t}$ $+\beta_{5}$ InfoAsym $_{i t}+\beta_{6} \log (\text { Age }+1)_{i t}+\beta_{7}$ MktShare $i t+\beta_{8}$ POS_ChgSale $i t+$

\footnotetext{
${ }^{10}$ Considering data availability, the definitions of both cross-shareholdings and other stable shareholdings
} follow those in the Data Package of Cross-Shareholding and Stable Shareholding (NLI Research Institute). 


$$
\begin{aligned}
& \beta_{9} N E G_{-} \text {ChgSale }_{i t}+\beta_{10} \text { ROA }_{i t}+\beta_{11} \text { MTB }_{i t}+\beta_{12} \text { AltmanZ }_{i t}+\beta_{13} \text { Leverage }_{i t}+ \\
& \beta_{14} C A_{i t}+\beta_{15} C L \_ \text {Xtrade }_{i t}+\beta_{16} \text { CashHold }_{i t}+\beta \text { INDUSTRY }+\beta \text { YEAR }+\varepsilon_{\mathrm{it}},
\end{aligned}
$$

TradeCredit ${ }_{i t}=\beta_{0}+\beta_{1} A Q_{i t-1}+\beta_{2} A Q_{i t-1} \times$ CrossSHD $_{i t-1}+\beta_{3} A Q_{i t-1} \times$ OtherStableSHD $_{i t-1}+$ $\beta_{4}$ CrossSHD $_{i t-1}+\beta_{5}$ OtherStableSHD $_{i t-1}+\beta_{6}$ LiquidCost $_{i t}+\beta_{7}$ InfoAsym $_{i t}+$

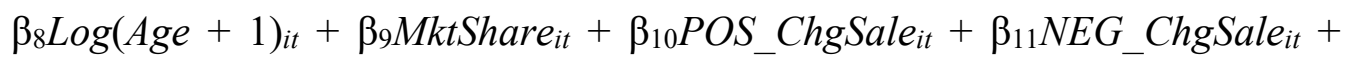
$\beta_{12}$ ROA $_{\text {it }}+\beta_{13}$ MTB $_{i t}+\beta_{14}$ AltmanZ $_{i t}+\beta_{15}$ Leverage $_{i t}+\beta_{16} C A_{i t}+\beta_{17} C L_{-}$Xtrade $_{i t}$ $+\beta_{18}$ CashHold $_{i t}+\beta$ INDUSTRY $+\beta$ YEAR $+\varepsilon_{i t}$.

StableSHD $=$ one if StableSH $>0$ and zero otherwise,

CrossSHD $=$ one if $C r o s s S H>0$ and zero otherwise, and

OtherStableSHD $=$ one if OtherStableSH $>0$ and zero otherwise.

Equations (1) - (5) are based on Chen et al.'s (2017) model. ${ }^{11}$ The independent variable, TradeCredit, is the ratio of trade credit to total assets. $A Q$ is a measure of accounting quality. $A Q$ is the first principal component score obtained using principal component analysis to extract the common component of firm-level accounting quality, in line with Beatty et al. (2010), Bharath et al. (2008), and Chen et al. (2017). ${ }^{12}$ Bharath, Sunder, and Sunder (2008) assert that this measure reduces the measurement error associated with each abnormal accrual measure. Three types of abnormal accrual measures $(A A 1, A A 2$, and $A A 3$ ) are used for principal component analysis. For $A A 1$, the absolute value of the residual of Dechow and Dichev's (2002) accrual model is standardized after multiplying by $-1, A A 2$ and $A A 3$ are computed similarly as $A A 1$ but based on Teoh, Welch, and

\footnotetext{
${ }^{11}$ The regression models in this study follow Chen et al. (2017) because the samples of both Chen et al. (2017) and this study samples are based on listed firms.

${ }^{12}$ This study assumes that suppliers offer trade credit based on the accounting quality and shareholdings that have already been disclosed to the public. Therefore, shareholding variables and $A Q$ are incorporated with a lag. This mitigates concerns about reverse causality. When using $A Q$ and shareholdings variables without a lag in equations (1) - (5), the results are similar to those presented in Table 4.
} 
Wong's (1998) model and Dechow, Sloan, and Sweeney's (1995) model, respectively. All three accrual models are estimated by industry-year, where industries are identified using the Tokyo Stock Exchange classification codes. ${ }^{13} A Q$ is computed as the first principal component score of $A A 1, A A 2$, and $A A 3$.

Following Chen et al. (2017), accounting accruals are computed using balance sheet and income statement data, because the calculation of accruals is modified to reduce the influence of change in accounts payable. Change in accounts payable is removed from the calculation of accruals. Because change in accounts payable is associated with change in inventories, the changes in inventory are regressed on the changes in accounts payable changes and the residuals of the regression are used as the modified change in inventories. ${ }^{14}$

The control variables in equation (1) are similar to those in Chen et al. (2017), and their definitions are provided in the Appendix. ${ }^{15}$ A positive $\beta_{1}$, the coefficient of $A Q$, indicates that accounting quality promotes the offering of trade credit from suppliers. Negative $\beta_{1}$ means that customers with low accounting quality might have difficulty accessing debt and equity financing, and thus need to increase trade credit in response to their financial constraints. Equation (1) does not isolate the effects of stable and crossshareholdings; thus, $\beta_{1}$ can be interpreted to include the effects of firms with and without cross- and stable shareholdings.

\footnotetext{
13 Sample firms are divided into 33 industries according to the Tokyo Stock Exchange classification codes. At least 20 observations in each industry-year group are required to calculate abnormal accruals. As a result, the primary test uses 25 industries to estimate Equation (1).

14 "Accruals" is defined as ( $\Delta$ current asset - $\Delta$ cash - $\Delta$ trading securities - $\Delta$ short-term loans receivable) ( $\Delta$ current liability - $\Delta$ short-term loan payable - $\Delta$ note payable for PPE - $\Delta$ accrued amount payable for PPE) - $\Delta$ long-term allowance - depreciation); PPE = the amount of property, plant, and equipment: all of the items are divided by total assets at the end of year $t-1$. To modify change in accounts payable, the change in accounts payable and the change in inventories are excluded and the residuals of regression of the change in inventories on the changes in accounts payable are added. For Dechow and Dichev's (2002) and Teoh et al.'s (1998) models, working capital accruals are used after eliminating non-working capital items. Because of the adjustments of accounts payable and inventories, accruals are calculated from balance sheet and income statements.

15 One exception from Chen et al's (2017) model is AltmanZ. They use S\&P credit ratings (PredRating) instead of AltmanZ. The database (Nikkei NEEDS-FinancialQUEST) does not include credit ratings.
} 
To test the hypothesis, equation (2) includes the corporate governance variables StableSH, CrossSH, and OtherStableSH. First, TradeCredit is regressed on AQ and its interaction with StableSH in Equation (2). As stable shareholdings can be split into crossshareholdings and other stable shareholdings (StableSH $=$ CrossSH + OtherStableSH), StableSH is replaced with CrossSH and OtherStableSH. CrossSH is the ratio of shares mutually held by financial institutions and other business corporations. OtherStableSH comprises the ratio of shares held by financial institutions, trust banks (for trading through their own account), and the parent company. Therefore, this variable is regarded as stable shareholdings by financial institutions for firms without a parent company because many banks, including non-main banks, hold listed firms' shares for the purposes of lending and the strength of their relationship.

Equation (2) allows the coefficients to differ between firms with and without stable shareholders and tests the differences in the effect of accounting quality between the two. As previously described, stable shareholdings are predicted to weaken the relationship between accounting quality and trade credit. For equation (2), the coefficients of $A Q$ and $A Q \times$ StableSH are predicted to have opposite signs. Thus, a positive (negative) coefficient of $A Q$ would suggest that firms with high $A Q$ and without stable shareholdings increase (decrease) the amount of trade credit, and a negative (positive) coefficient of $A Q$ $\times$ StableSH means that close ties to stable shareholders cancel out the effect of the coefficient of $A Q .^{16}$

Therefore, $\beta_{1}$ is the effect of $A Q$ on a firm without stable shareholdings, and $\beta_{1}+$ $\beta_{2} \times$ StableSH is the total effect of $A Q$ when $A Q$ is fixed. $\beta_{2} \times$ StableSH is the incremental effect on a firm with stable shareholdings compared to one without stable shareholdings. In this study, if the absolute value of the total effect $\left(\beta_{1}+\beta_{2} \times\right.$ StableSH) is smaller than

\footnotetext{
${ }^{16} \beta_{1}$ in the equation (2) shows the mixed results of (a) the positive effects of accounting quality on the amount of trade credit and (b) the weakening effect of presence of private information between suppliers and customers (without stable shareholdings) on (a). Positive $\beta_{1}$ shows that the former effect dominates the latter. $\beta_{3}$ represents the direct effect of stable shareholdings on trade credit. When close ties to stable shareholdings could increase a firm's credibility, the sign of $\beta_{3}$ is expected to be positive.
} 
that of $\beta_{1}$, the hypothesis is supported in terms of reducing the effect of $A Q$ through stable shareholdings.

Consider the case in which $\beta_{1}\left(\beta_{2}\right)$ is positive (negative). $\beta_{2} \times$ StableSH is nonpositive because StableSH is nonnegative. Then, the nonnegative total impact of $A Q$ $\left(\beta_{1}+\beta_{2} \times\right.$ StableSH $\left.\geqq 0\right)$ implies that the effect of $A Q$ on trade credit is reduced by the intersection term. Even when the total impact of $A Q$ is negative, but higher than $-\beta_{1}\left(-\beta_{1}\right.$ $<\beta_{1}+\beta_{2} \times$ StableSH $<0$ ), the total effect of accounting quality decreases in absolute value relative to the effect without stable shareholdings, which supports the hypothesis.

For equation (3), I focus on the coefficients of the two interaction terms $\beta_{2}$ and $\beta_{3}$ in equation (3). When the sign of $\beta_{1}$ in equation (3) is positive, $\beta_{2}$ and $\beta_{3}$ are expected to be negative in contrast to $\beta_{1}$, and vice versa. The interpretation of the coefficient is similar to that of equation (2). I replace the continuous stable and cross-shareholding variables with dummy variables in equations (4) and (5). In the case of equation (4), when the sign of $\beta_{1}$ is positive, $\beta_{2}$ is expected to be negative, in contrast to $\beta_{1}$. The coefficients in equation (5) are predicted in a similar manner.

\section{Sample selection and data collection}

Table 1 summarizes the study's sample-selection procedure. The initial sample comprises nonfinancial firms with consolidated financial statement data from 2001 to 2016. To eliminate the impact of IFRS on accounting practices, the sample is limited to firms that have adopted Japanese GAAP. Firm years in which total assets and/or sales growth exceeds 100 percent are excluded to avoid the effect of major changes to business fundamentals, such as large M\&As (Almeida, Campello, and Weisbach 2004; Hribar and Collins 2001). Firm-years that do not have sufficient data to calculate accounting accruals are also excluded. Finally, firm-years without data on cross- and stable shareholdings or without the data necessary to calculate control variables are deleted. The final sample yields 27,794 firm-year observations. 
[Insert Table 1 about here]

Data are obtained from three databases. All data on financial statements are obtained from Nikkei NEEDS-FinancialQUEST (Nikkei Media Marketing). The data on cross- and stable shareholdings are derived from the Data Package of Cross-Shareholding and Stable Shareholding (NLI Research Institute). Stock price data are obtained from NPM (Financial Data Solutions).

\section{RESULTS}

Panel A of Table 2 reports the descriptive statistics for the dependent and independent variables used to analyze the relationship between accounting quality and trade credit. The mean of TradeCredit is 0.144 (median $=0.122$ ). Cross-shareholders hold approximately 10 percent of shares on average, while stable shareholders hold over 20 percent, implying that cross- and stable shareholders still have substantially influence corporate governance in Japan. Panels B and C of Table 2 report the descriptive statistics for firms with and without stable shareholdings. Firms with stable shareholdings have significantly higher trade credit and accounting quality and are larger than firms without stable shareholdings but show a lower return on assets (ROA). Almost all variables are significantly different between firms with and without stable shareholdings. These results suggest that firms without stable shareholdings may have less access to trade credit because of lower accounting quality despite better performance, whilefirms with stable shareholdings might be actively trading within the corporate group.

Table 3 shows the Pearson correlation matrix. No high correlation coefficient is observed within the independent variables; therefore, the results of the regressions reported in this section are not influenced by multicollinearity. ${ }^{17}$

17 Since the variance inflation factors for the primary tests are below ten, the multicollinearity does not 
[Insert Table 2 about here]

[Insert Table 3 about here]

Table 4 presents the regression results of equations (1) - (5). ${ }^{18}$ In Column (1), the coefficient of $A Q$ is not significant. These results could be a mixture of those for firms with and without stable shareholdings. Columns (2) and (3) report the results of testing the hypotheses using the interaction effect of $A Q$ with StableSH, CrossSH, and OtherStableSH. Column (2) shows that the coefficient of $A Q$ is significantly positive, indicating that accounting quality has a positive effect on trade credit when stable shareholdings are zero. ${ }^{19}$ This study's results are consistent with those of Garcia-Teruel et al. (2014) but conflict with those of Chen et al. (2017). The firms with stable shareholdings, which are a large portion of the sample, may have driven the results.

The coefficient $\left(\beta_{2}\right)$ of the interaction term $(A Q \times S t a b l e S H)$ has a significantly negative sign in contrast to the coefficient of $A Q\left(\beta_{1}\right)$, which is consistent with the hypothesis. The relationship between accounting quality and trade credit without stable shareholdings is observed only when the impact of firms with stable shareholdings is isolated from the results in Column (1). This implies that stable shareholders have a proportional impact on the relationship between accounting quality and trade credit.

Substituting the estimated coefficients $\left(\beta_{1}\right.$ and $\left.\beta_{2}\right)$ and value of StableSH into $\beta_{1}+$ $\beta_{2} \times$ StableSH, when StableSH are higher than 35.5 percent (23.0 percent of the sample), trade credit is negatively related to accounting quality $\left(\beta_{1}+\beta_{2} \times\right.$ StableSH $\left.<0\right)$, albeit to a

\footnotetext{
appear to affect the results.

${ }_{18}$ All continuous variables at the top and bottom 1 percent are winsorized to limit the influence of outliers.

19 In Japan and Spain, the majority of trade credit contracts do not have cash discounts contracts in common (Uesugi et al. 2009; García-Teruel et al. 2014). In the US, Ng et al. $(1999,1110)$ report that "2/10 net 30" contracts are frequently observed in their sample. This contract means the combination of 2 percent discount for payment within 10 days and a net period of 30 days. The implicit interest rate is 43.9 percent. The results of this study imply that Japanese and Spanish suppliers consider accounting quality when offering trade credit without discounts. Meanwhile, US firms with little access to traditional financing because of low accounting quality would seek to obtain trade credit despite the high-interest rate.
} 
smaller degree. ${ }^{20}$ Then, the incremental effect of $A Q$ with stable shareholdings $\left(\beta_{2} \times\right.$ StableSH) outweighs the effect $\left(\beta_{1}\right)$ of $A Q$ without them; however, the absolute value of the total effect does not exceed the absolute value of the $A Q$ effect without stable shareholdings $\left(\mid \beta_{1}+\beta_{2} \times\right.$ StableSH $\left.|<| \beta_{1} \mid\right)$, and the (absolute) effect of $A Q$ is weakened by the incremental effect. Thus, the hypothesis is supported.

The findings show that an increase in stable shareholdings decreases the importance of accounting quality for supply and/or demand of trade credits. Thus, close ties to stakeholders, including suppliers, could encourage the exchange of private information instead of public disclosure. Column (4) shows a significantly negative coefficient of $A Q \times$ StableSHD, suggesting a decrease in the effect of accounting quality owing to the existence of stable shareholdings. Almost all of the control variables are significant, except for CashHold.

\section{[Insert Table 4 about here]}

In Column (3), StableSH is replaced with CrossSH and OtherStableSH. The coefficients of $A Q \times$ Cross SH and $A Q \times$ OtherStableSH are significantly negative, in contrast to the coefficient of $A Q\left(\beta_{1}\right)$, indicating that close ties to cross-shareholders or other financial shareholders reduce the association between accounting quality and trade credit. ${ }^{21}$ Similar to the results in Column (2), when cross- and other stable shareholders are high (37.8 percent of the sample), trade credit is negatively related to accounting quality, albeit to a smaller degree. ${ }^{22}$ However, the absolute value of the total effect does

\footnotetext{
${ }^{20}$ I calculated this by substituting the value of StableH and the unrounded coefficients $\left(\beta_{1}\right.$ and $\beta_{2}$ ). The value of $\beta_{1}$ and $\beta_{2}$ before rounding are 0.0028476 and -0.0080147 , respectively.

${ }^{21}$ The coefficient of $A Q \times$ CrossSH is significantly negative when CrossSH and OtherStableSH-related variables are incorporated separately.

${ }^{22}$ I calculated this by substituting the value of CrossSH and OtherStableSH and the unrounded coefficients $\left(\beta_{1}, \beta_{2}\right.$, and $\left.\beta_{3}\right)$. The values of $\beta_{1}, \beta_{2}$, and $\beta_{3}$ before rounding are $0.0041575,-0.0273567$, and -0.0067929 , respectively. Unlike stable shareholders, the magnitude of incremental effect depends on the combination of two variables (CrossSH and OtherStableSH). It is impossible to report the specific values for CrossSH and OtherStableSH so that the total effect would be negative.
} 
not exceed that of the original $A Q$ effect without cross- or other stable shareholdings. Column (5) reports similar results.

The coefficients of StableSH, CrossSH, OtherStableSH, and StableSHD are significantly positive in Columns (2), (3), and (4). The results indicate that, in total, close ties to stable shareholders increase trade credit. ${ }^{23}$ Essentially, when customers are in the same business group as suppliers, they can receive more trade credit from those suppliers. ${ }^{24}$

The aforementioned results can also be interpreted another way. Given that either accounting quality or stable shareholdings increase the amount of trade credit, the effects of accounting quality and stable shareholdings cancel each other out because of the negative sign of their interaction term $(A Q \times$ Stable $S H)$. The reason for this is the substitution between public and private information.

From the mid-1990s to the mid-2000s, cross- and stable shareholdings weakened between the mid-1990s and mid-2000s. Unwinding cross- and stable shareholdings appears to have enhanced the role of accounting information in trade credit.

\section{ADDITIONAL TESTS AND ROBUSTNESS CHECKS}

\section{Additional testing: Effects of bank shareholdings}

As an additional test, this study analyzes bank shareholdings as another feature of Japanese-style shareholdings. ${ }^{25}$ Japanese banks supply funds to lender firms with whom

\footnotetext{
${ }^{23}$ The coefficients of CrossSH, OtherStableSH, CrossSHD, and OtherStableSHD are significantly positive when they are incorporated separately.

${ }^{24}$ The results are consistent with Hoshi, Kashyap, and Scharfstein (1990), who state that financial links between Japanese firms could encourage suppliers to extend trade credit to customers and customers to buy from suppliers within the industrial group.

${ }^{25}$ In Japan, banks are permitted to hold shares in non-financial firms up to a specified ratio (five percent), as in European countries. Based on previous studies, Ono, Suzuki, and Uezugi $(2018,1)$ explain two reasons why both main and non-main banks hold borrowers' equity claims. They summarize that the motivation of holding a borrower's shares is to (1) obtain a competitive advantage from complementary effects between shareholdings and lending activity and (2) mitigate the conflict of interest between shareholder and borrowers.
} 
they have long-term relationships, often hold their shares, and are involved in their management, especially when lender firms face financial difficulties (Douthett and Jung 2001; Hoshi and Kashyap 2001; Jacobson and Aaker 1993; Sheard 1994). The main bank is that with the closest link to client firms and provides daily and primary financial services. As a result, the main bank holds a prominent position in providing financing to client firms and is at the core of the cross-shareholder group; in many cases, it also has close ties to the lender firm. Thus, main banks acquire private information on lender firms through daily activities. Some other banks also hold the lender's shares; therefore, they can also obtain private information on the lender firm.

Such close ties to lender firms encourage communication of private information with those firms. Shuto, Kitagawa, and Futaesaku (2017) report on the acquisition of private information and the monitoring effect under the main bank, documenting that bondholders delegate monitoring to bond issuers' main banks that share their private information. ${ }^{26}$ Therefore, suppliers could utilize not only their own private information but also banks' monitoring with private information owned by banks. Previous trade credit studies have not focused on this phenomenon.

In line with the above argument, the present study focuses on bank shareholdings to observe the banks' effect on trade credit by including three bank-related variables. Instead of cross- and stable shareholdings in equation (2), the following variables are incorporated: the ratio of bank shareholdings $(B a n k S H)$, the ratio of main bank shareholdings (MainBankSH), and the ratio of other bank shareholdings except main bank shareholding (OtherBanksSH_MB). In line with the primary tests, I also include the ratio of shares held by cross-shareholding banks (BankCrossSH) and the ratio of other bank shareholdings, except for bank cross-shareholdings (OtherBanksSH_BCSH). BankSH is a proxy for the strength of all bank shareholdings comprising main and non-main banks.

\footnotetext{
${ }^{26}$ Nagata and Nguyen (2017) report that bank shareholdings lead to lower-quality disclosure, owing to the accessibility of private information. The results of this study also provide evidence regarding the possibility of sharing private information.
} 
MainBankSH represents the main bank's influence as a shareholder. BankCrossSH extracts a particularly strong (cross-holding) relationship between banks and firms. Higher values indicate stronger ties to banks and thus increase the potential to use private instead of public information. The "main bank" for each firm is defined as the top-ranked bank on the list of Nikkei primary trading banks (Nikkei Shuyo-Torihiki-Ginko), which is compiled via a questionnaire survey distributed to all listed firms regarding their trading banks. $^{27}$

The following regressions are run to test the bank relationship:

$$
\begin{gathered}
\text { TradeCreditit }=\beta_{0}+\beta_{1} A Q_{i t-1}+\beta_{2} A Q_{i t-1} \times \text { BankSH }_{i t-1}+\beta_{3} \text { BankSH }_{i t-1}+\beta \text { Controls } \\
+\beta \text { INDUSTRY }+\beta \text { YEAR }+\varepsilon_{i t},
\end{gathered}
$$

TradeCredit $_{i t}=\beta_{0}+\beta_{1} A Q_{i t-1}+\beta_{2} A Q_{i t-1} \times$ MainBankSH $_{i t-1}+\beta_{3} A Q_{i t-1} \times$ OtherBanksSH_MB $B_{i t-1}+\beta_{4}$ MainBankSH $H_{i t-1}+\beta_{5}$ OtherBanksSH_MB $B_{i t-1}$

$+\beta$ Controrls $+\beta$ INDUSTRY $+\beta$ YEAR $+\varepsilon_{i t}$

TradeCredit $_{i t}=\beta_{0}+\beta_{1} A Q_{i t-1}+\beta_{2} A Q_{i t-1} \times$ BankCrossSH $_{i t-1}+\beta_{3} A Q_{i t-1} \times$ OtherBanksSH_BCSH $H_{i t-1}+\beta_{4}$ BankCrossSH $H_{i t-1}+\beta_{5}$ OtherBanksSH_BCSH $H_{i t-1}$ $+\beta$ Controls $+\beta$ INDUSTRY $+\beta$ YEAR $+\varepsilon_{i t}$,

Along with the primary tests, I replace bank shareholdings variables with dummy variables as follows:

TradeCredit $_{i t}=\beta_{0}+\beta_{1} A Q_{i t-1}+\beta_{2} A Q_{i t-1} \times$ BankSHD $_{i t-1}+\beta_{3}$ BankSHD $_{i t-1}+\beta$ Controls $\beta$

$$
I N D U S T R Y+\beta Y E A R+\varepsilon_{i t}
$$

\footnotetext{
27 In this questionnaire survey, each firm ranks the banks from which it receives primary financial services, irrespective of shareholdings or loan shares. This study posits that the bank at the top of the list serves as the main bank. Similar procedures are used in other research on main banks.
} 
TradeCredit $_{i t}=\beta_{0}+\beta_{1} A Q_{i t-1}+\beta_{2} A Q_{i t-1} \times$ MainBankSHD $_{i t-1}+\beta_{3} A Q_{i t-1} \times$ OtherBanksSHD_MB $B_{i t-1}+\beta_{4}$ MainBankSHD ${ }_{i t-1}+\beta_{5}$ OtherBanksSHD_MB $B_{i t-1}+$ $\beta$ Controls $+\beta$ INDUSTRY $+\beta$ YEAR $+\varepsilon_{i t}$,

TradeCredit $_{i t}=\beta_{0}+\beta_{1} A Q_{i t-1}+\beta_{2} A Q_{i t-1} \times$ BankCrossSHD $_{i t-1}+\beta_{3} A Q_{i t-1} \times$ OtherBanksSHD_BCSH $H_{i t-1}+\beta_{4}$ BankCrossSHD ${ }_{i t-1}+\beta_{5}$ OtherBanksSHD_BCSH ${ }_{i t-1}$ $+\beta$ Controls $+\beta$ INDUSTRY $+\beta$ YEAR $+\varepsilon_{i t}$,

where:

BankSH $=$ the ratio of shares held by banks,

MainbankSH = the ratio of shares held by the main bank,

OtherBanksSH_MB = BankSH-MainBankSH,

BankCross $S H=$ the ratio of shares held by cross-shareholding banks,

OtherBanksSH_BCSH $=$ BankSH - BankCrossSH,

BankSHD $=$ one if BankSH $>0$ and zero otherwise,

MainbankSHD = one if MainbankSH $>0$ and zero otherwise,

OtherBanksSHD_MB $=$ one if OtherBanksSH_MB $>0$ and zero otherwise,

BankCross $S H D=$ one if BankCrossSH $>0$ and zero otherwise, and

OtherBanksSHD_BCSH $=$ one if OtherBanksSHD_BCSH $>0$ and zero otherwise. ${ }^{28}$

The coefficients of the interaction terms, which are $\beta_{2}$ in equations (6) and (9) and $\beta_{2}$ and $\beta_{3}$ in equations (7), (8), (10), and (11), are predicted to have negative signs, in contrast to the coefficient of $A Q\left(\beta_{1}\right)$, as in the primary tests.

Table 5 presents the results from equations (6) - (11). All the coefficients of the

\footnotetext{
${ }^{28}$ As previously mentioned, an upper limit on holding shares in non-financial firms is five percent for banks. Hence, the sample excludes firm-year observations in which a bank has shareholdings over five percent.
} 
interaction terms of $A Q$ with bank shareholding variables are significantly negative. These results are consistent with those on cross- and stable shareholdings. The ties to banks (the main bank) with shareholdings also appear to lower the importance of accounting information for trade credit. ${ }^{29}$ In Column (1), when bank shareholdings are higher than 6.5 percent (38.0 percent of the sample in Column 1), trade credit is negatively related to accounting quality $\left(\beta_{1}+\beta_{2} \times B a n k S H<0\right) .{ }^{30}$ Further, 16.7 percent of observations are the absolute value of the total effect exceeding the absolute value of the original $A Q$ effect without bank shareholdings $\left(\mid \beta_{1}+\beta_{2} \times\right.$ BankSH $\left.|>| \beta_{1} \mid\right)$. Thus, the total effect of $A Q$ does not increase by the intersection term in 16.7 percent of the sample. The results hold for Columns (2) and (3).

The additional findings generally imply that suppliers as financing providers may delegate customer monitoring to banks with whom they have close ties. However, the findings also suggest the possibility that customers with high bank shareholdings rely (in part) on trade credit for short-term financing despite low accounting quality. With higher bank shareholdings, trade credit might be supplied with information other than accounting, such as close ties to banks.

[Insert Table 5 about here]

\footnotetext{
29 Thus, in addition to capital ties, main bank dependency is tested as a borrowing tie (MainBankBorrowing = bank borrowing from the main bank / total borrowings) to the main bank to consider another type of main bank tie. However, the coefficient of the interaction term of $A Q$ with MainBankBorrowings is not significant. Although the strengthening of the main bank tie to shareholdings increases trade credit, ties by debt dependency do not affect trade credit. This result can be interpreted as follows. The increase of bank borrowing strengthens a tie to banks. The increase could reduce the importance of accounting figures according to strengthening the tie through bank borrowings. However, the increase could make banks pay more attention to accounting information. Thus, the mixed effect could make the results ambiguous.

${ }^{30}$ I calculated this by substituting the value of $B a n k H$ and the unrounded coefficients $\left(\beta_{1}\right.$ and $\beta_{2}$ ). The values of $\beta_{1}$ and $\beta_{2}$ before rounding are 0.004156 and -0.064126 , respectively.
} 


\section{Robustness checks}

I perform four sensitivity tests to confirm the robustness of the primary results. First, to alleviate concerns over the problems of correlated omitted variables, I replace the industry-fixed effects with firm-fixed effects in the regressions, which control for timeinvariant firm-specific characteristics. Table 6 shows the regression results for the firmfixed effect. The primary results in Table 3 are robust to the replacement of industry-fixed effects with firm-fixed effects, except for the coefficients of $A Q$ and $A Q \times$ OtherStable $S H \cdot{ }^{31}$

[Insert Table 6 about here]

The results in Columns (4) and (5) show that firms that unwind stable shareholdings and/or cross-shareholdings reduce the relationship between accounting quality and trade credit, compared to firms that maintain stable shareholdings. These results can be interpreted as those for the difference-in-difference approach, because firm-fixed and shareholding dummies are included. ${ }^{32}$

Second, cross-shareholdings with banks are considered to address the possibility that banks' cross-shareholdings may drive the primary results, as described in the additional tests. To exclude the competing explanation, the bank's cross-shareholdings are subtracted from CrossSH, and equation (3) is re-estimated. ${ }^{33}$ The coefficient of the

\footnotetext{
${ }^{31}$ Of the results, 2 percent in Column (2) and 3 percent in Column (3) do not support the hypothesis (the absolute value of the total effect exceeds the absolute value of the $A Q$ effect without stable shareholdings) 32 The coefficient of $A Q \times$ StableSHD is the difference between the coefficient of $A Q$ for firms without change in the presence of stable shareholders and those with change.

${ }^{33}$ Specifically, the following regression is estimated;

TradeCredit $t_{i t}=\beta_{0}+\beta_{1} A Q_{i t-1}+\beta_{2} A Q_{i t-1} \times$ CrossSHexcludingBanks $i_{t-1}+\beta_{3} A Q_{i t-1} \times$ BankCrossSH $_{i t-1}+\beta_{5} A Q_{i t-}$ ${ }_{1} \times$ OtherStableSH $_{i t-1}+\beta_{6}$ CrossSHexcludingBanks $_{i t-1}+\beta_{7}$ BankCrossSH $_{i t-1}+\beta_{8}$ OtherStableSH $_{i t-1}+\beta$ where,$$
\text { Controls }+\beta \text { INDUSTRY }+\beta \text { YEAR }+\varepsilon_{i t}
$$

CrossSHexcludingBanks $=$ CrossSH - BankCrossSH, and

BankCross $S H=$ the ratio of shares held by banks who mutually hold the shares.

When the value of BankCrossSH is more than that of CrossSH all three CrossSH-related variables are replaced with missing values. This is because BankCrossSH are calculated based on Nikkei-
} 
interaction term of $A Q$ with the part of cross-shareholdings, excluding those of banks, remains significantly negative (not tabulated). Hence, the primary results are robust, even when banks collect private information.

Third, I employ two alternative accrual models from Jones (1991) and Kothari, Leone, and Wasley (2005). The results remain unchanged when using both models. Finally, three accounting quality measures were used separately before summarizing them using principal component analysis (non-tabulated). For $A A 1$ and $A A 2$, the coefficients of $A Q \times$ StableSH and $A Q \times C r o s s S H$ are consistent with the hypothesis. When $A A 3$ is used, only the coefficient of $A Q \times C r o s S S H$ is significantly negative. ${ }^{34}$ Overall, the results for the other accounting quality measures are consistent with those shown in Table 4, although some of the results do not support the hypothesis (see footnote 34 ).

\section{CONCLUSION}

This study investigates the effect of close ties to stakeholders on the relationship between accounting quality and trade credit in Japan, which is an important extension of previous studies on accounting quality and debt. This study uses well-known features of Japanese corporate governance: cross- and stable shareholdings. Firms closely relate to each other through cross- and stable shareholdings, and it is posited that they exchange private information through its mechanism.

In general, study highlights that cross- and stable shareholdings weaken the relationship between accounting quality and trade credit. These findings suggest that, in Japan, close ties to cross- and stable shareholders reduce the importance of accounting

FinancialQUEST (CrossSH is derived from Data Package of Cross-Shareholding and Stable Shareholding). 34 The third and fourth robustness tests employ two and three accounting accrual models, respectively. When $A Q$ in equation (2) is replaced by each accounting accrual measure, all results were similar to those in Table 4, except that Teoh et al. (1998) model's measure does not support the hypothesis with 1.5 percent of the observations $\left(\left|\beta_{1}\right|<\mid \beta_{1}+\beta_{2} \times\right.$ StableSH $\left.\mid\right)$. For equation (3), 0.01 percent of the observations when using Jones's (1991) model, 0.2 percent when using Kothari et al.'s (2005) model, 5.18 percent when using Dechow et al's. (1998) model, 1.27 percent when using Dechow and Dichev's (2002) model, and 13.31 percent when using Dechow et al.'s (1995) model do not support the hypothesis. 
information through sharing private information in various relationships, including implicit contracts.

This study also indicates that the trade credit of customers without cross- or stable shareholdings increases with accounting quality. The results conflict with those for US firms in Chen et al. (2017) but consistent with those in Garcia-Teruel et al. (2014). The present findings study suggests that the relationship between accounting quality and trade credit depends on the characteristics of the country, which contributes to an understanding of international accounting.

In an additional test, the replacement of cross- and stable shareholdings with bank shareholdings produces results similar to the primary findings. The results imply the possibility of the monitoring effect being delegated to banks in bank-firm relationships in Japan. However, this does not mean that bank shareholding effects dominate those of cross- and stable shareholdings, because the primary results are robust to the test that isolates banks' cross-shareholdings from total cross-shareholdings.

Cross-shareholdings are intimately related to the Japanese bank system, which is also well-known for Japanese corporate governance. From the viewpoint of the exchange of private information, more detailed research on the role if banks in trade credit could be an avenue of interest for future research. The analyses in this study could be extended to research on the exchange of private information among stakeholders, which lead to a similar decrease in the importance of accounting information used in contracts. 


\section{REFERENCES}

Almeida, H, M. Campello, and M. S. Weisbach. 2004. The cash flow sensitivity of cash. The Journal of Finance 59 (4): 1777-1804.

Altman, E. 1968. Financial ratios, discriminant analysis and prediction of corporate bankruptcy. The Journal of Finance 23 (4): 589-609.

Aoki, M., G. Jackson, and H. Miyajima. 2007. Corporate Governance in Japan: Institutional Change and Organizational Diversity. Oxford: University Press, New York.

Aoki, M., and H. T. Patrick. 1994. The Japanese Main Bank System: Its Relevance for Developing and Transforming Economies. Oxford: University Press, New York.

Bae, K. H., and J. -B. Kim. 1998. The usefulness of earnings and book value for predicting stock returns and cross corporate ownership in Japan. Japan and the World Economy 10 (4): 1-15.

Ball, R., S. P. Kothari, and A. Robin. 2000. The effect of international institutional factors on properties of accounting earnings. Journal of Accounting and Economics 29 (1): $1-51$.

Ball, R., and L. Shivakumar. 2005. Earnings quality in UK private firms: Comparative loss recognition timeliness. Journal of Accounting and Economics 39 (1): 83-128.

Beatty, A., S. Liao, and J. Weber. 2010. The effect of private information and monitoring on the role of accounting quality in investment. Contemporary Accounting Research 27 (1): 14-47.

Berglof, E., and E. Perotti. 1994. The governance structure of the Japanese financial keiretsu. Journal of Financial Economics 36 (2): 259-284.

Bharath, S. T., J. Sunder, and S. Sunder. 2008. Accounting quality and debt contracting. The Accounting Review 83 (1): 1-28.

Biddle, G., and G. Hilary. 2006. Accounting quality and firm-level capital investment. The Accounting Review 81 (5): 963-982. 
Chen, D., M. Liu, T. Ma, and X. Martin. 2017. Accounting quality and trade credit. Accounting Horizons 31 (3): 69-83.

Cooke, T. E. 1996. The Influence of the Keiretsu on Japanese corporate disclosure. Journal of International Financial Management and Accounting 7 (3): 191-214.

Dechow, P. M., and I. D. Dichev. 2002. The quality of accruals and earnings: The role of accrual estimation errors. The Accounting Review 77 (4): 35-59.

Dechow, P. M., R. G. Sloan, and A. Sweeney. 1995. Detecting earnings management. The Accounting Review 70 (2): 193-225.

Douthett, E. B., and K. Jung. 2001. Japanese corporate groupings (keiretsu) and the informativeness of earnings. Journal of International Financial Management and Accounting 12 (2): 133-159.

Elemes, A. and A. Filip. 2022. Financial reporting quality and private firms' access to trade credit capital. The International Journal of Accounting 57 (2): 2250010.

El Ghoul, S., and X. Zheng. 2016. Trade credit provision and national culture. Journal of Corporate Finance 41: 475-501.

Francis, J., R. LaFond, P. Olsson, and K. Schipper. 2004. Costs of equity and earnings attributes. The Accounting Review 79 (4): 967-1010.

Francis, J., R. LaFond, P. Olsson, and K. Schipper. 2005. The market pricing of accruals quality. Journal of Accounting and Economics 39 (2): 295-327.

García-Teruel, P. J., and P. Martínez-Solano. 2010. A dynamic approach to accounts receivable: A study for Spanish SMEs'. European Financial Management 16 (3): $400-421$.

García-Teruel, P. J., P. Martínez-Solano, and J. P. Sanchez-Ballesta. 2014. Supplier financing and earnings quality. Journal of Business Finance and Accounting, 41 (9-10): 1193-1211.

Ge, W., and J.-B. Kim. 2014. Real earnings management and the cost of new corporate bonds. Journal of Business Research 67 (4): 641-647. 
Giannetti, M., M. Burkart, and T. Ellingsen. 2008. What you sell is what you lend? Explaining trade credit contracts. The Review of Financial Studies 24 (4): 12611298.

Gilson, R. J., and M. J. Roe. 1993. Understanding the Japanese keiretsu: overlaps between corporate governance and industrial organization. Yale Law Journal 102 (4): 871906.

Goto, A. 1982. Business groups in a market economy. European Economic Review 19 (1): 53-70.

Hasan, I., J. C. Park, and Q. Wu. 2012. The impact of earnings predictability on bank loan contracting. Journal of Business Finance and Accounting 39 (7-8): 1068-1101.

Hoshi, T., A. Kashyap, and D. Scharfstein. 1990. The role of banks in reducing the costs of financial distress in Japan. Journal of Financial Economics 27 (1): 67-88.

Hoshi, T., and A. Kashyap. 2001. Corporate Financing and Governance in Japan: The Road to the Future. Cambridge, MA: MIT Press.

Hribar, P., and D. W. Collins. 2002. Errors in estimating accruals: Implications for empirical research. Journal of Accounting Research 40 (1): 105-134.

Ikeda, N., Inoue, K., and Watanabe, S. (2018). Enjoying the quiet life: Corporate decision-making by entrenched managers. Journal of the Japanese and International Economies. 47: 55-69.

Jacobson, R., and D. Aaker. 1993. Myopic management behavior with efficient, but imperfect, financial markets: A comparison of information asymmetries in the U.S. and Japan. Journal of Accounting and Economics 16 (4): 383-405.

Jiang, L., and J. -B. Kim. 2000. Cross-corporate ownership, information asymmetry and the usefulness of accounting performance measures in Japan. The International Journal of Accounting 35 (1): 85-98.

Jones, J. J. 1991. Earnings management during import relief investigations. Journal of Accounting Research 29 (2): 193-228. 
Klapper, L., L. Laeven, and R. Rajan. 2012. Trade credit contracts. Review of Financial Studies 25 (3): 838-867.

Kothari, S. P., A. J. Leone, and C. E. Wasley. 2005. Performance matched discretionary accrual measures. Journal of Accounting and Economics 39 (1): 163-197.

Lambert, R., C. Leuz, and R. Verrecchia. 2007. Accounting information, disclosure, and the cost of capital. Journal of Accounting Research 45 (2): 385-420.

Lau, C. M., and U. Schaede, U. 2020. Of substitutes and complements: trade credit versus bank loans in Japan, 1980-2012. Review of Quantitative Finance and Accounting 55 (1): $305-326$.

Levine, R., C. Lin, and W. Xie. 2018. Corporate resilience to banking crises: The roles of trust and trade credit. Journal of Financial and Quantitative Analysis 53 (4): $1441-1477$.

Li, X., J. Ng, and W. Saffer. (2021). Financial reporting and trade credit: Evidence from Mandatory IFRS adoption. Contemporary Accounting Research 38 (1): 96-128.

McGuire, J., and S. Dow. 2003. The persistence and implications of Japanese keiretsu organization. Journal of International Business Studies 34 (4): 374-388.

McGuire, J., and S. Dow. 2009. Japanese keiretsu: Past, present, future. Asia Pacific Journal of Management 26 (2): 333-351.

Miwa, Y., and M. Ramseyer. 2008. Trade credit, bank loans, and monitoring: Evidence from Japan. Journal of Economics and Management Strategy 17 (2): 317-343.

Miyajima, H., and F. Kuroki. 2007. The unwinding of cross-shareholding in Japan: Causes, effects, and implications, In Aoki, M., G. Jackson and H. Miyajima (eds.) Corporate Governance in Japan: Institutional Change and Organizational Diversity, Oxford: Oxford University Press. 79-124.

Nagata, K., and P. Nguyen. 2017. Ownership structure and disclosure quality: Evidence from management forecasts revisions in Japan. Journal of Accounting and Public Policy 36 (6): 451-467. 
Ng, C. K., J. K. Smith, and R. L. Smith. 1999. Evidence on the determinants of credit terms used in interfirm trade. The Journal of Finance 54 (3): 1109-1129.

Ono. A., K. Suzuki, and I. Uezugi. 2018. When Japanese Banks Become Pure Creditors: Effects of Declining Shareholding by Banks on Bank Lending and Firms' Risk Taking. RIETI Discussion Paper Series 17-E-079.

Osano, H. 1996. Intercorporate shareholdings and corporate control in the Japanese firm. Journal of Banking and Finance 20 (6): 1047-1068.

Petersen, M., and R. Rajan. 1997. Trade credit: Theories and evidence. Review of Financial Studies 10 (3): 661-691.

Pike, R., and N. S. Cheng. 2001. Credit management: An examination of policy choices, practices and late payment in UK companies. Journal of Business Finance and Accounting 28 (7-8): 1013-1142.

Sheard, P. 1989. The main bank system and corporate monitoring and control in Japan. Journal of Economic Behavior and Organization 11 (3): 399-422.

Sheard, P. 1991. The Economics of interlocking shareholding in Japan. Ricerche Economiche 45: 421-448.

Sheard, P. 1994. Main banks and the governance of financial distress. In M. Aoki and H. Patrick (Eds.), The Japanese Main-Bank System: Its Relevance for Developing and Transforming Economies. New York, NY: Oxford University Press. 188-230.

Shuto, A., N. Kitagawa, and N. Futaesaku. 2017. The Effect of Bank Monitoring on the Demand for Earnings Quality in Bond Contracts. IMES Discussion paper series. Discussion Paper No. 2017-E-12.

Teoh, S., I. Welch, and T. Wong. 1998. Earnings management and the long-run market performance of initial public offerings. The Journal of Finance 53 (6): 1935-1974.

Uchida, H., I. Uesugi, and M. Hotei. 2010. Repayment Enforcement and Informational Advantages: Empirical Determinants of Trade Credit Use. RIETI Discussion Paper Series (Vol. 10). 
Uesugi, I., H. Uchida, Y. Ogura, A. Ono, P. Xu, D. Tsuruta, T. Nemoto, H. Hirata, Y. Yasuda, N. Yamori, W. Watanabe, and M. Hotei. 2009. Kinyu-kikika ni Okeru Chusho-Kigyo-Kinyu no Genjou (The Current Status of SME Financing under the Financial Crisis: A Summary of the Survey on the Status of Transactions between Businesses and Financial Institutions (Feb. 2008) and the Survey on the Status of Transactions between Businesses and Financial Institutions (Feb. 2009)). RIETI Discussion Paper Series 09-J-020. (in Japanese)

Yoshikawa, T., and P. Phan, P. 2001. Alternative corporate governance systems in Japanese firms: Implications for a shift to stockholder-centered corporate governance. Asia Pacific Journal of Management 18 (2): 183-205. 


\section{APPENDIX}

Definition of variables

\begin{tabular}{|c|c|}
\hline Variable & Definition \\
\hline \multicolumn{2}{|c|}{ Independent variable } \\
\hline TradeCredit & $=$ Accounting payable divided by total assets \\
\hline \multicolumn{2}{|c|}{ Accounting quality variables } \\
\hline$A Q$ & $\begin{aligned}= & \text { Accounting quality measure, the first principal component } \\
& \text { score of } A A 1, A A 2, \text { and } A A 3\end{aligned}$ \\
\hline$A A 1$ & $\begin{array}{l}=\text { Abnormal accruals, which is computed as the absolute } \\
\text { value of the residual of Dechow and Dichev's (2002) } \\
\text { accrual model. The absolute value of residual is multiplied } \\
\text { by }-1 \text { and standardized. }\end{array}$ \\
\hline$A A 2$ & $\begin{array}{l}=\text { Abnormal accruals, which is computed as the absolute } \\
\text { value of the residual of Teoh et al.'s (1998) model. The } \\
\text { absolute value of the residual is multiplied by }-1 \text { and } \\
\text { standardized. }\end{array}$ \\
\hline$A A 3$ & $\begin{array}{l}=\text { Abnormal accruals, which are computed as the absolute } \\
\text { value of the residual in Dechow et al.'s (1995) model. The } \\
\text { absolute value of the residual is multiplied by }-1 \text { and } \\
\text { standardized. }\end{array}$ \\
\hline
\end{tabular}

\section{Shareholder variables}

StableSH

CrossSH

OtherStableSH

StableSHD

Cross SHD

OtherStableSHD

$=$ The ratio of shares held by stable shareholders, which are the sum of CrossSH and OtherStableSH

$=$ The ratio of shares mutually held by financial institutions and other business corporations

$=$ The ratio of shares held by financial institutions, trust banks (for trading through their own accounts), and the parent company

$=$ One if StableSH $>0$ and zero otherwise.

$=$ One if Cross $S H>0$ and zero otherwise

$=$ One if OtherStableSH $>0$ and zero otherwise.

\section{Control variables}

CA

CashHold

CL_XTrade

InfoAsym

$=$ Non-cash current assets divided by total assets

$=$ The sum of cash to marketable securities divided by total assets

$=$ Current liabilities subtracting accounting payable divided by total assets

$=$ Decile rankings of mean bid-ask spread in year $t-1$ 
Leverage

$$
\begin{aligned}
& \text { LiquidCost } \\
& \text { Log }(\text { Age }+1) \\
& \text { Log }(\text { Asset }) \\
& \text { MktShare }
\end{aligned}
$$

$M T B$

NEG_ChgSale

POS_ChgSale

AltmanZ

$R O A$

\section{Bank variables}

BankSH

MainBankSH

OtherBanksSH_MB

BankCrossSH

OtherBanksSH_BCSH

BankSHD

MainbankSHD

OtherBanksSHD MB

BankCrossSHD

OtherBanksSHD BCSH
$=$ Long-term debt and debt in current liabilities divided by total assets

$=$ Raw material divided by total assets

$=$ Natural logarithm of firm age plus 1

$=$ Natural logarithm of total assets

$=$ Market share, which is the ratio of a firm's sales to total sales in the same industry. The Tokyo Stock Exchange classification codes are used to divide the sample into industries.

$=$ Market value of equity to the book value of net assets.

$=$ Negative sales change divided by total assets

$=$ Positive sales change divided by total assets

$=$ Altman Z-score (Altman 1968)

$=$ Net income over total assets

$=$ The ratio of shares held by banks

$=$ The ratio of shares held by the main bank

$=$ BankSH - MainBankSH

$=$ The ratio of shares held by cross-shareholding banks,

$=$ BankSH - BankCrossSH,

$=$ One if BankSH $>0$ and zero otherwise.

$=$ One if MainbankSH $>0$ and zero otherwise.

$=$ One if OtherBanksSH $M B>0$ and zero otherwise.

$=$ One if BankCross $S H>0$ and zero otherwise.

$=$ One if OtherBanksSH_BCSH>0 and zero otherwise. 


\section{Table 1.}

Sample selection procedure

\begin{tabular}{lr}
\hline & Firm-years \\
\hline Firm-years from 2001 to 2016 that adopt Japanese GAAP, not included in banks, & 46,613 \\
securities firms, insurance firms, or other financial industries & \\
(Less) Firm-years with total assets or sales growth over 100 percent & $(476)$ \\
(Less) Firm-years without sufficient data for calculating accounting quality & $(8,671)$ \\
(Less) Firm-years without cross- and stable shareholdings data & $(5,958)$ \\
(Less) Firm-years without data for control variables & $(3,714)$ \\
Firm- years observations for our primary analysis & 27,794 \\
\hline
\end{tabular}


Table 2.

Panel A. Descriptive statistics of dependent and independent variables

\begin{tabular}{lrrrrr}
\hline Variables & Mean & $\mathrm{Q} 1$ & Median & Q3 & SD \\
\hline TradeCredit & 0.144 & 0.063 & 0.122 & 0.195 & 0.110 \\
AQ & 0.062 & -0.378 & 0.474 & 0.951 & 1.343 \\
StableSH & 0.230 & 0.084 & 0.195 & 0.339 & 0.178 \\
CrossSH & 0.096 & 0.018 & 0.076 & 0.148 & 0.089 \\
OtherStableSH & 0.134 & 0.019 & 0.060 & 0.158 & 0.172 \\
StableSHD & 0.950 & 1 & 1 & 1 & 0.218 \\
CrossSHD & 0.854 & 1 & 1 & 1 & 0.353 \\
OtherStableSHD & 0.865 & 1 & 1 & 1 & 0.342 \\
CA & 0.376 & 0.263 & 0.375 & 0.485 & 0.167 \\
CashHold & 0.159 & 0.072 & 0.128 & 0.212 & 0.120 \\
CL_XTrade & 0.205 & 0.119 & 0.184 & 0.269 & 0.114 \\
InfoAsym & 5.498 & 3.000 & 5.000 & 8.000 & 2.872 \\
Leverage & 0.202 & 0.045 & 0.169 & 0.321 & 0.175 \\
LiquidCost & -0.017 & -0.027 & -0.004 & 0.000 & 0.024 \\
Log(Age+1) & 3.952 & 3.786 & 4.075 & 4.251 & 0.511 \\
Log(Asset) & 11.113 & 10.148 & 10.981 & 11.972 & 1.431 \\
MktShare & 0.011 & 0.001 & 0.003 & 0.009 & 0.024 \\
MTB & 1.310 & 0.655 & 0.968 & 1.523 & 1.143 \\
NEG_ChgSale & -0.036 & -0.033 & 0.000 & 0.000 & 0.079 \\
POS_ChgSale & 0.062 & 0.000 & 0.020 & 0.084 & 0.098 \\
AltmanZ & 1.121 & 0.757 & 0.990 & 1.346 & 0.568 \\
ROA & 0.022 & 0.007 & 0.022 & 0.043 & 0.046 \\
\hline
\end{tabular}

Panel B. Descriptive statistics for the firms without stable shareholdings

\begin{tabular}{lrrrrr}
\hline Variables & Mean & Q1 & Median & Q3 & SD \\
\hline TradeCredit & $0.075^{* * *}$ & 0.014 & $0.048^{* * *}$ & 0.101 & 0.085 \\
AQ & $-0.449^{* * *}$ & -1.061 & $0.080^{* * *}$ & 0.689 & 1.628 \\
CA & $0.307^{* * *}$ & 0.176 & $0.289^{* * *}$ & 0.409 & 0.172 \\
CashHold & $0.296^{* * *}$ & 0.144 & $0.276^{* * *}$ & 0.441 & 0.178 \\
CL_XTrade & $0.223^{* * *}$ & 0.121 & $0.193^{* * *}$ & 0.293 & 0.136 \\
InfoAsym & $6.261^{* * *}$ & 4.000 & $7.000^{* * *}$ & 9.000 & 2.936 \\
Leverage & $0.182^{* * *}$ & 0.011 & $0.115^{* * *}$ & 0.307 & 0.191 \\
LiquidCost & $-0.008^{* * *}$ & -0.006 & $0.000^{* * *}$ & 0.000 & 0.019 \\
Log(Age+1) & $3.173^{* * *}$ & 2.735 & $3.087^{* * *}$ & 3.584 & 0.604 \\
Log(Asset) & $9.705^{* * *}$ & 8.369 & $9.339^{* * *}$ & 10.805 & 1.578 \\
MktShare & $0.004^{* * *}$ & 0.000 & $0.001^{* * *}$ & 0.003 & 0.013 \\
MTB & $2.507^{* * *}$ & 1.020 & $1.793^{* * *}$ & 3.274 & 2.033 \\
NEG_ChgSale & $-0.050^{* * *}$ & -0.041 & 0.000 & 0.000 & 0.106 \\
POS_ChgSale & $0.110^{* * *}$ & 0.000 & $0.038^{* * *}$ & 0.170 & 0.149 \\
AltmanZ & $1.230^{* * *}$ & 0.688 & $1.104^{* * *}$ & 1.550 & 0.733 \\
ROA & 0.022 & -0.011 & $0.032^{* * *}$ & 0.075 & 0.085 \\
\hline
\end{tabular}


Panel C. Descriptive statistics for the firms with stable shareholdings

\begin{tabular}{lrrrrr}
\hline Variables & Mean & Q1 & Median & Q3 & SD \\
\hline TradeCredit & 0.148 & 0.068 & 0.126 & 0.199 & 0.110 \\
AQ & 0.089 & -0.345 & 0.491 & 0.962 & 1.321 \\
CA & 0.380 & 0.269 & 0.379 & 0.488 & 0.166 \\
CashHold & 0.151 & 0.070 & 0.124 & 0.203 & 0.111 \\
CL_XTrade & 0.204 & 0.118 & 0.183 & 0.268 & 0.113 \\
InfoAsym & 5.458 & 3.000 & 5.000 & 8.000 & 2.863 \\
Leverage & 0.203 & 0.047 & 0.171 & 0.321 & 0.174 \\
LiquidCost & -0.017 & -0.027 & -0.004 & 0.000 & 0.024 \\
Log(Age + 1) & 3.994 & 3.847 & 4.089 & 4.262 & 0.471 \\
Log(Asset) & 11.187 & 10.228 & 11.024 & 12.023 & 1.383 \\
MktShare & 0.011 & 0.001 & 0.003 & 0.009 & 0.025 \\
MTB & 1.247 & 0.645 & 0.948 & 1.465 & 1.039 \\
NEG_ChgSale & -0.035 & -0.033 & 0.000 & 0.000 & 0.078 \\
POS_ChgSale & 0.059 & 0.000 & 0.019 & 0.081 & 0.093 \\
AltmanZ & 1.115 & 0.759 & 0.985 & 1.336 & 0.557 \\
ROA & 0.022 & 0.007 & 0.022 & 0.042 & 0.043 \\
\hline The variable definitions are provided in the Appendix. N $=27,794,($ Panel A), 1,391 (Panel B) \\
and 26,403 (Panel C) & & & &
\end{tabular}


Table 3.

Correlation matrix

\begin{tabular}{|c|c|c|c|c|c|c|c|c|c|c|c|c|c|c|c|c|c|c|c|c|c|c|c|}
\hline & & (1) & (2) & (3) & (4) & (5) & (6) & (7) & (8) & (9) & (10) & (11) & (12) & (13) & (14) & (15) & (16) & (17) & (18) & (19) & (20) & (21) & (22) \\
\hline (1) & TradeCredit & 1 & & & & & & & & & & & & & & & & & & & & & \\
\hline (2) & $A Q$ & -0.09 & 1 & & & & & & & & & & & & & & & & & & & & \\
\hline (3) & StableSH & 0.21 & -0.03 & 1 & & & & & & & & & & & & & & & & & & & \\
\hline (4) & CrossSH & 0.12 & 0.09 & 0.31 & 1 & & & & & & & & & & & & & & & & & & \\
\hline$(5)$ & OtherStableSH & 0.15 & -0.08 & 0.87 & -0.20 & 1 & & & & & & & & & & & & & & & & & \\
\hline (6) & StableSHD & 0.14 & 0.09 & 0.30 & 0.25 & 0.18 & 1 & & & & & & & & & & & & & & & & \\
\hline (7) & CrossSHD & 0.11 & 0.11 & 0.18 & 0.45 & -0.04 & 0.55 & 1 & & & & & & & & & & & & & & & \\
\hline (8) & OtherStableSHD & 0.12 & 0.05 & 0.38 & 0.16 & 0.31 & 0.58 & 0.25 & 1 & & & & & & & & & & & & & & \\
\hline (9) & $C A$ & 0.64 & -0.19 & 0.19 & 0.03 & 0.18 & 0.09 & 0.05 & 0.09 & 1 & & & & & & & & & & & & & \\
\hline (10) & CashHold & -0.20 & 0.00 & -0.30 & -0.23 & -0.19 & -0.26 & -0.24 & -0.26 & -0.23 & 1 & & & & & & & & & & & & \\
\hline (11) & CL_XTrade & -0.02 & -0.11 & 0.02 & -0.05 & 0.05 & -0.04 & -0.06 & 0.03 & 0.12 & -0.23 & 1 & & & & & & & & & & & \\
\hline (12) & InfoAsym & 0.14 & -0.10 & 0.09 & 0.03 & 0.07 & -0.06 & -0.08 & -0.02 & 0.11 & 0.00 & 0.15 & 1 & & & & & & & & & & \\
\hline (13) & Leverage & -0.10 & -0.02 & 0.00 & 0.06 & -0.03 & 0.03 & 0.04 & 0.08 & -0.09 & -0.42 & 0.67 & 0.09 & 1 & & & & & & & & & \\
\hline (14) & LiquidCost & 0.06 & 0.01 & -0.02 & -0.05 & 0.00 & -0.08 & -0.07 & -0.06 & -0.17 & 0.08 & 0.01 & -0.01 & -0.03 & 1 & & & & & & & & \\
\hline (16) & $\log ($ Asset $)$ & 0.02 & 0.14 & 0.10 & 0.14 & 0.02 & 0.23 & 0.26 & 0.16 & -0.04 & -0.28 & -0.02 & -0.67 & 0.15 & -0.01 & 0.28 & 1 & & & & & & \\
\hline (17) & MktShare & -0.06 & 0.07 & -0.01 & 0.04 & -0.03 & 0.07 & 0.10 & 0.07 & -0.08 & -0.15 & 0.03 & -0.39 & 0.15 & 0.00 & 0.12 & 0.64 & 1 & & & & & \\
\hline (18) & MTB & -0.11 & -0.09 & -0.14 & -0.22 & -0.03 & -0.24 & -0.24 & -0.16 & -0.10 & 0.18 & 0.24 & -0.15 & 0.11 & 0.09 & -0.23 & -0.03 & 0.05 & 1 & & & & \\
\hline (19) & NEG_ChgSale & -0.07 & 0.15 & -0.01 & 0.05 & -0.04 & 0.04 & 0.05 & 0.02 & -0.11 & -0.03 & -0.09 & -0.10 & -0.06 & 0.03 & 0.04 & 0.12 & 0.06 & 0.04 & 1 & & & \\
\hline (20) & POS_ChgSale & 0.19 & -0.13 & -0.06 & -0.11 & -0.01 & -0.11 & -0.13 & -0.09 & 0.16 & 0.07 & 0.02 & -0.01 & -0.08 & 0.03 & -0.18 & -0.06 & -0.03 & 0.24 & 0.29 & 1 & & \\
\hline (21) & PredRating & 0.50 & -0.12 & 0.01 & -0.10 & 0.07 & -0.04 & -0.11 & -0.03 & 0.33 & -0.02 & 0.09 & 0.09 & -0.11 & 0.12 & -0.20 & -0.14 & -0.09 & 0.05 & -0.12 & 0.35 & 1 & \\
\hline (22) & $R O A$ & -0.06 & 0.02 & -0.08 & -0.08 & -0.04 & 0.00 & -0.04 & -0.05 & -0.03 & 0.21 & -0.23 & -0.19 & -0.31 & 0.02 & -0.07 & 0.07 & 0.02 & 0.18 & 0.30 & 0.29 & 0.05 & 1 \\
\hline
\end{tabular}

Table 3 presents a Pearson correlation matrix. Variable definitions are provided in the Appendix. $N=27,794$. 
Table 4.

Accounting quality and trade credit: Main results

\begin{tabular}{|c|c|c|c|c|c|}
\hline Variable & $(1)$ & (2) & (3) & (4) & $(5)$ \\
\hline \multirow[t]{2}{*}{ Intercept } & $-0.193 * * *$ & $-0.188 * * *$ & $-0.182 * * *$ & $-0.194 * * *$ & $-0.189 * * *$ \\
\hline & $(0.023)$ & $(0.023)$ & $(0.023)$ & $(0.023)$ & $(0.023)$ \\
\hline \multirow[t]{2}{*}{$A Q$} & 0.001 & $0.003 * * *$ & $0.004 * * *$ & $0.010 * * *$ & $0.010 * * *$ \\
\hline & $(0.000)$ & $(0.001)$ & $(0.001)$ & $(0.002)$ & $(0.002)$ \\
\hline$A Q \times$ & & $-0.008 * * *$ & & & \\
\hline StableSH & & $(0.003)$ & & & \\
\hline$A Q \times$ & & & $-0.027 * * *$ & & \\
\hline CrossSH & & & $(0.006)$ & & \\
\hline$A Q \times$ & & & $-0.007 * *$ & & \\
\hline OtherStableSH & & & $(0.003)$ & & \\
\hline \multirow{2}{*}{ StableSH } & & $0.021 * * *$ & & & \\
\hline & & $(0.008)$ & & & \\
\hline \multirow{2}{*}{ CrossSH } & & & $0.063 * * *$ & & \\
\hline & & & $(0.016)$ & & \\
\hline \multirow{2}{*}{ OtherStableSH } & & & $0.018 * *$ & & \\
\hline & & & $(0.008)$ & & \\
\hline$A Q \times$ & & & & $-0.010 * * *$ & \\
\hline StableSHD & & & & $(0.002)$ & \\
\hline$A Q \times$ & & & & & $-0.005 * * *$ \\
\hline CrossSHD & & & & & $(0.001)$ \\
\hline$A Q \times$ & & & & & $-0.006^{* * *}$ \\
\hline OtherStableSHD & & & & & $(0.002)$ \\
\hline \multirow{2}{*}{ StableSHD } & & & & $0.013 * * *$ & \\
\hline & & & & $(0.005)$ & \\
\hline \multirow{2}{*}{ CrossSHD } & & & & & 0.005 \\
\hline & & & & & $(0.003)$ \\
\hline \multirow{2}{*}{ OtherStableSHD } & & & & & 0.005 \\
\hline & & & & & $(0.003)$ \\
\hline \multirow[t]{2}{*}{$C A$} & $0.301 * * *$ & $0.299 * * *$ & $0.301 * * *$ & $0.301 * * *$ & $0.301 * * *$ \\
\hline & $(0.012)$ & $(0.012)$ & $(0.012)$ & $(0.012)$ & $(0.012)$ \\
\hline \multirow[t]{2}{*}{ CashHold } & -0.001 & 0.007 & 0.007 & 0.001 & 0.001 \\
\hline & $(0.011)$ & $(0.011)$ & $(0.011)$ & $(0.011)$ & $(0.011)$ \\
\hline \multirow[t]{2}{*}{ CL_XTrade } & $-0.170 * * *$ & $-0.172 * * *$ & $-0.170 * * *$ & $-0.170 * * *$ & $-0.171 * * *$ \\
\hline & $(0.015)$ & $(0.015)$ & $(0.015)$ & $(0.015)$ & $(0.015)$ \\
\hline \multirow[t]{2}{*}{ InfoAsym } & $0.007 * * *$ & $0.006 * * *$ & $0.006 * * *$ & $0.006 * * *$ & $0.006 * * *$ \\
\hline & $(0.001)$ & $(0.001)$ & $(0.001)$ & $(0.001)$ & $(0.001)$ \\
\hline \multirow[t]{2}{*}{ Leverage } & $0.020^{*}$ & $0.025^{* *}$ & $0.023 * *$ & $0.020^{* *}$ & $0.020 * *$ \\
\hline & $(0.010)$ & $(0.010)$ & $(0.010)$ & $(0.010)$ & $(0.010)$ \\
\hline \multirow[t]{2}{*}{ LiquidCost } & $0.351 * * *$ & $0.344 * * *$ & $0.348 * * *$ & $0.361 * * *$ & $0.360 * * *$ \\
\hline & $(0.047)$ & $(0.047)$ & $(0.047)$ & $(0.047)$ & $(0.047)$ \\
\hline \multirow[t]{2}{*}{$\log (A g e+1)$} & $0.017 * * *$ & $0.016^{* * *}$ & $0.014 * * *$ & $0.015 * * *$ & $0.015 * * *$ \\
\hline & $(0.003)$ & $(0.003)$ & $(0.003)$ & $(0.003)$ & $(0.003)$ \\
\hline $\log ($ Asset $)$ & $0.015^{* * *}$ & $0.014 * * *$ & $0.014 * * *$ & $0.014 * * *$ & $0.014 * * *$ \\
\hline
\end{tabular}




\begin{tabular}{|c|c|c|c|c|c|}
\hline & $(0.002)$ & $(0.002)$ & $(0.002)$ & $(0.002)$ & $(0.002)$ \\
\hline \multirow[t]{2}{*}{ MktShare } & $-0.247 * * *$ & $-0.227 * * *$ & $-0.213 * * *$ & $-0.234 * * *$ & $-0.236 * * *$ \\
\hline & $(0.053)$ & $(0.054)$ & $(0.054)$ & $(0.054)$ & $(0.054)$ \\
\hline \multirow[t]{2}{*}{$M T B$} & $0.006 * * *$ & $0.006 * * *$ & $0.006 * * *$ & $0.007 * * *$ & $0.007 * * *$ \\
\hline & $(0.001)$ & $(0.001)$ & $(0.001)$ & $(0.001)$ & $(0.001)$ \\
\hline \multirow[t]{2}{*}{ NEG_ChgSale } & $0.034 * * *$ & $0.033 * * *$ & $0.030 * * *$ & $0.032 * * *$ & $0.031 * * *$ \\
\hline & $(0.010)$ & $(0.010)$ & $(0.010)$ & $(0.010)$ & $(0.010)$ \\
\hline \multirow[t]{2}{*}{ POS_ChgSale } & $0.026 * * *$ & $0.028 * * *$ & $0.029 * * *$ & $0.028 * * *$ & $0.028 * * *$ \\
\hline & $(0.009)$ & $(0.009)$ & $(0.009)$ & $(0.009)$ & $(0.009)$ \\
\hline \multirow[t]{2}{*}{ PredRating } & $0.063 * * *$ & $0.062 * * *$ & $0.062 * * *$ & $0.063 * * *$ & $0.063 * * *$ \\
\hline & $(0.004)$ & $(0.004)$ & $(0.004)$ & $(0.004)$ & $(0.004)$ \\
\hline \multirow[t]{2}{*}{$R O A$} & $-0.183^{* * *}$ & $-0.183^{* * *}$ & $-0.182 * * *$ & $-0.193 * * *$ & $-0.190 * * *$ \\
\hline & $(0.021)$ & $(0.021)$ & $(0.021)$ & $(0.021)$ & $(0.021)$ \\
\hline Industry FE & included & Included & included & included & included \\
\hline Year FE & included & Included & included & included & included \\
\hline Adjusted R-squared & 0.648 & 0.649 & 0.650 & 0.649 & 0.650 \\
\hline Observations & 27,794 & 27,794 & 27,794 & 27,794 & 27,794 \\
\hline
\end{tabular}

Robust standard errors clustered by firm are shown in parentheses. ${ }^{* * *}{ }^{* *}$, and ${ }^{*}$ indicate significance at 1 percent, 5 percent, and 10 percent levels, respectively (two-tailed). The dependent variable is TradeCredit. Variable definitions are provided in the Appendix. Columns (1), (2), (3), (4), and (5) show the results for equations (1), (2), (3), (4), and (5), respectively.

TradeCredit $_{i t}=\beta_{0}+\beta_{1} A Q_{i t-1}+\beta_{2}$ LiquidCost $_{i t}+\beta_{3}$ InfoAsym $_{i t}+\beta_{4} \log (\text { Asset })_{i t}+\beta_{5} \log (\text { Age }+1)_{i t}+\beta_{6}$ MktShare $_{i t}+$

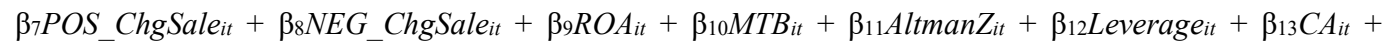
$\beta_{14} C L \_$XTrade $_{i t}+\beta_{15}$ CashHold $_{i t}+\beta$ INDUSTRY $+\beta$ YEAR $+\varepsilon_{i t}$,

TradeCreditit $=\beta_{0}+\beta_{1}$ AQ $_{i t-1}+\beta_{2}$ AQ $Q_{i t-1} \times$ StableSH $_{i t-1}+\beta_{3}$ StableSH $_{i t-1}+\beta_{4}$ LiquidCost $_{i t}+\beta_{5}$ InfoAsym $_{i t}+\beta_{6} \log ($ Age + $1)_{i t}+\beta_{7}$ MktShare $_{i t}+\beta_{8} P O S \_$ChgSale $i t+\beta_{9}$ NEG_ChgSale $i t+\beta_{10}$ ROA $_{i t}+\beta_{11}$ MTB $_{i t}+\beta_{12}$ AltmanZ $_{i t}+$ $\beta_{13}$ Leverage $_{i t}+\beta_{14} C_{i t}+\beta_{15}$ CL_XTrade ${ }_{i t}+\beta_{16}$ CashHold $_{i t}+\beta$ INDUSTRY $+\beta$ YEAR $+\varepsilon_{\mathrm{it}}$,

TradeCreditit $=\beta_{0}+\beta_{1} A Q_{i t-1}+\beta_{2} A Q_{i t-1} \times$ CrossSH $_{i t-1}+\beta_{3} A Q_{i t-1} \times$ OtherStableSH $_{i t-1}+\beta_{4}$ CrossSH $_{i t-1}+\beta_{5}$ OtherStableSH $_{i t-}$ ${ }_{1}+\beta_{6}$ LiquidCost $_{i t}+\beta_{7}$ InfoAsym $_{i t}+\beta_{8} \log (\text { Age }+1)_{i t}+\beta_{9}$ MktShare $i t+\beta_{10}$ POS_ChgSale $i t+\beta_{11}$ NEG_ChgSale $i t$ $+\beta_{12}$ ROA $_{i t}+\beta_{13}$ MTB $_{i t}+\beta_{14}$ AltmanZ $_{i t}+\beta_{15}$ Leverage $_{i t}+\beta_{16}$ CA $_{i t}+\beta_{17} C L \_$XTrade $_{i t}+\beta_{18}$ CashHold $_{i t}+\beta$ INDUSTRY $+\beta$ YEAR $+\varepsilon_{i t}$.

TradeCreditit $=\beta_{0}+\beta_{1} A Q_{i t-1}+\beta_{2}$ AQ $_{i t-1} \times$ StableSHD $_{i t-1}+\beta_{3}$ StableSHD $_{i t-1}+\beta_{4}$ LiquidCost $_{i t}+\beta_{5}$ InfoAsym $_{i t}+\beta_{6} \log ($ Age $+1)_{i t}+\beta_{7}$ MktShare $_{i t}+\beta_{8} P O S_{-}$ChgSale $i t+\beta_{9} N E G_{-}$ChgSale $i t+\beta_{10}$ ROA $_{i t}+\beta_{11}$ MTB $_{i t}+\beta_{12}$ AltmanZ $_{i t}+$ $\beta_{13}$ Leverage $_{i t}+\beta_{14} C A_{i t}+\beta_{15}$ CL_XTrade ${ }_{i t}+\beta_{16}$ CashHold $_{i t}+\beta$ INDUSTRY $+\beta$ YEAR $+\varepsilon_{i t}$,

TradeCreditit $=\beta_{0}+\beta_{1} A Q_{i t-1}+\beta_{2} A Q_{i t-1} \times$ CrossSHD $_{i t-1}+\beta_{3} A Q_{i t-1} \times$ OtherStableSHD $_{i t-1}+\beta_{4}$ CrossSHD $_{i t-1}+\beta_{5}$ OtherStableSHD ${ }_{i t-1}+\beta_{6}$ LiquidCost $_{i t}+\beta_{7}$ InfoAsym $_{i t}+\beta_{8} \log (\text { Age }+1)_{i t}+\beta_{9}$ MktShare $_{i t}+\beta_{10}$ POS_ChgSale $_{i t}+$

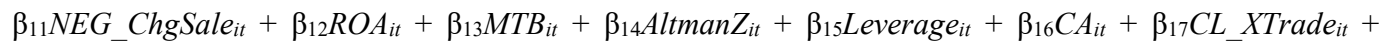
$\beta{ }_{18}$ CashHoldit $+\beta$ INDUSTRY $+\beta$ YEAR $+\varepsilon i t$. 
Table 5.

Accounting quality and trade credit: Results of bank variables

\begin{tabular}{|c|c|c|c|c|c|c|}
\hline Variable & $(1)$ & $(2)$ & (3) & $(4)$ & $(5)$ & $(6)$ \\
\hline Intercept & $\begin{array}{c}-0.195 * * * \\
(0.023)\end{array}$ & $\begin{array}{c}-0.197 * * * \\
(0.023)\end{array}$ & $\begin{array}{c}-0.198 * * * \\
(0.023)\end{array}$ & $\begin{array}{c}-0.197 * * * \\
(0.023)\end{array}$ & $\begin{array}{c}-0.199 * * * \\
(0.023)\end{array}$ & $\begin{array}{c}-0.199 * * * \\
(0.023)\end{array}$ \\
\hline$A Q$ & $\begin{array}{c}0.004 * * * \\
(0.001)\end{array}$ & $\begin{array}{c}0.005^{* * *} \\
(0.001)\end{array}$ & $\begin{array}{c}0.004 * * * \\
(0.001)\end{array}$ & $\begin{array}{c}0.007 * * * \\
(0.001)\end{array}$ & $\begin{array}{c}0.006 * * * \\
(0.001)\end{array}$ & $\begin{array}{c}0.006 * * * \\
(0.001)\end{array}$ \\
\hline$A Q \times B a n k S H$ & $\begin{array}{c}-0.064 * * * \\
(0.011)\end{array}$ & & & & & \\
\hline$A Q \times$ MainBankSH & & $\begin{array}{c}-0.106 * * * \\
(0.033)\end{array}$ & & & & \\
\hline$A Q \times$ OtherBanksSH_MB & & $\begin{array}{c}-0.046 * * * \\
(0.015)\end{array}$ & & & & \\
\hline$A Q \times$ CrossBankSH & & & $\begin{array}{c}-0.063 * * * \\
(0.013)\end{array}$ & & & \\
\hline$A Q \times$ OtherBanksSH_BCSH & & & $\begin{array}{c}-0.066^{* * *} \\
(0.017)\end{array}$ & & & \\
\hline BankSH & $\begin{array}{c}0.034 \\
(0.029)\end{array}$ & & & & & \\
\hline MainBankSH & & $\begin{array}{c}0.143 * * \\
(0.071)\end{array}$ & & & & \\
\hline OtherBanksSH_MB & & $\begin{array}{l}-0.007 \\
(0.036)\end{array}$ & & & & \\
\hline CrossBankSH & & & $\begin{array}{c}0.012 \\
(0.032)\end{array}$ & & & \\
\hline OtherBanksSH_CBSH & & & $\begin{array}{c}0.102 * * \\
(0.040)\end{array}$ & & & \\
\hline$A Q \times B a n k S H D$ & & & & $\begin{array}{c}-0.008 * * * \\
(0.002)\end{array}$ & & \\
\hline$A Q \times$ MainBankSHD & & & & & $\begin{array}{c}-0.004 * * * \\
(0.001)\end{array}$ & \\
\hline$A Q \times$ OtherBanksSHD_MB & & & & & $\begin{array}{c}-0.003 * * * \\
(0.001)\end{array}$ & \\
\hline$A Q \times$ CrossBankSHD & & & & & & $\begin{array}{c}-0.005^{* * *} \\
(0.001)\end{array}$ \\
\hline$A Q \times$ OtherBanksSHD_BCSH & & & & & & $\begin{array}{c}-0.004 * * * \\
(0.001)\end{array}$ \\
\hline BankSHD & & & & $\begin{array}{c}0.010^{* * *} \\
(0.003)\end{array}$ & & \\
\hline MainBankSHD & & & & & $\begin{array}{c}0.005 * * \\
(0.003)\end{array}$ & \\
\hline OtherBanksSHD_MB & & & & & $\begin{array}{c}0.003 \\
(0.003)\end{array}$ & \\
\hline CrossBankSHD & & & & & & $\begin{array}{c}0.001 \\
(0.003)\end{array}$ \\
\hline OtherBanksSHD_CBSH & & & & & & $0.006^{* * *}$ \\
\hline
\end{tabular}




\begin{tabular}{lcccccc} 
Control Variables & included & included & included & included & included & included \\
Industry FE & included & included & included & included & included & included \\
Year FE & included & included & included & included & included & included \\
Adjusted R-squared & 0.649 & 0.650 & 0.650 & 0.650 & 0.650 & 0.650 \\
Observations & 25,973 & 25,854 & 25,973 & 25,973 & 25,854 & 25,973 \\
\hline
\end{tabular}

Robust standard errors clustered by firm are shown in parentheses. ${ }^{* * *},{ }^{* *}$, and ${ }^{*}$ indicate significance at 1 percent, 5 percent, and 10 percent levels, respectively (two-tailed). The dependent variable is TradeCredit. Variable definitions are provided in the Appendix. Columns (1), (2), (3), (4), (5) and (6) show the results for equations (6), (7), (8), (9), (10) and (11), respectively.

TradeCredit ${ }_{i t}=\beta_{0}+\beta_{1} A Q_{i t-1}+\beta_{2} A Q_{i t-1} \times$ BankSH $_{i t-1}+\beta_{3}$ BankSH $_{i t-1}+\beta_{4}$ LiquidCost $_{i t}+\beta_{5}$ InfoAsym $_{i t}+\beta_{6} \log (\text { Age }+1)_{i t}+$

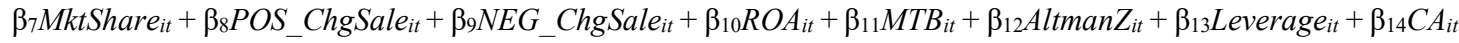
$+\beta_{15}$ CL_XTrade ${ }_{i t}+\beta_{16}$ CashHold $_{i t}+\beta$ INDUSTRY $+\beta$ YEAR $+\varepsilon_{i t}$,

TradeCredit ${ }_{i t}=\beta_{0}+\beta_{1} A Q_{i t-1}+\beta_{2} A Q_{i t-1} \times$ MainBankSH $_{i t-1}+\beta_{3} A Q_{i t-1} \times$ OtherBanksSH_MB $B_{i t-1}+\beta_{4}$ MainBankSH $_{i t-1}+\beta_{5}$ OtherBanksSH_MBit-1 $+\beta_{6}$ LiquidCost $_{i t}+\beta_{7}$ InfoAsym $_{i t}+\beta_{8} \log (\text { Age }+1)_{i t}+\beta_{9}$ MktShare $i t+\beta_{10}$ POS_ChgSale ${ }_{i t}+$ $\beta_{11} N E G_{-}$ChgSale ${ }_{i t}+\beta_{12}$ ROA $_{i t}+\beta_{13}$ MTB $_{i t}+\beta_{14}$ Altman $_{i t}+\beta_{15}$ Leverage $_{i t}+\beta_{16}$ CA $_{i t}+\beta_{17} C L \_$XTrade $_{i t}+\beta_{18}$ CashHold $_{i t}$ $+\beta$ INDUSTRY $+\beta$ YEAR $+\varepsilon_{i t}$,

TradeCreditit $=\beta_{0}+\beta_{1} A Q_{i t-1}+\beta_{2} A Q_{i t-1} \times$ BankCrossSH $H_{i t-1}+\beta_{3} A Q_{i t-1} \times$ OtherBanksSH_BCSH $H_{i t-1}+\beta_{4}$ BankCrossSH $_{i t-1}+\beta_{5}$ OtherBanksSH_BCSH ${ }_{i t-1}+\beta_{6}$ LiquidCost $_{i t}+\beta_{7}$ InfoAsym $_{i t}+\beta_{8} \log (\text { Age }+1)_{i t}+\beta_{9}$ MktShare $i t+\beta_{10}$ POS_ChgSale It $_{i}+$ $\beta_{11}$ NEG_ChgSale $_{i t}+\beta_{12}$ ROA $_{i t}+\beta_{13}$ MTB $_{i t}+\beta_{14}$ AltmanZ $_{i t}+\beta_{15}$ Leverage $_{i t}+\beta_{16}$ CA $_{i t}+\beta_{17} C L \_X$ XTrade $_{i t}+$ $\beta_{18}$ CashHoldit $+\beta$ INDUSTRY $+\beta$ YEAR $+\varepsilon_{i t}$

TradeCredit ${ }_{i t}=\beta_{0}+\beta_{1} A Q_{i t-1}+\beta_{2} A Q_{i t-1} \times$ BankSHD $_{i t-1}+\beta_{3}$ BankSHD $_{i t-1}+\beta_{4}$ LiquidCost $_{i t}+\beta_{5}$ InfoAsym $_{i t}+\beta_{6} \log (\text { Age }+1)_{i t}+$ $\beta_{7}$ MktShare $_{i t}+\beta_{8}$ POS_ChgSale ${ }_{i t}+\beta_{9} N E G_{-}$ChgSale ${ }_{i t}+\beta_{10}$ ROA $_{i t}+\beta_{11}$ MTB $_{i t}+\beta_{12}$ AltmanZ $_{i t}+\beta_{13}$ Leverage $_{i t}+\beta_{14}$ CA $_{i t}$ $+\beta_{15} C L \_$TTrade $_{i t}+\beta{ }_{16}$ CashHoldit $_{+}+\beta$ INDUSTRY $+\beta$ YEAR $+\varepsilon i t$,

TradeCredit $t_{i t}=\beta_{0}+\beta_{1} A Q_{i t-1}+\beta_{2} A Q_{i t-1} \times$ MainBankSHD $D_{i t-1}+\beta_{3} A Q_{i t-1} \times$ OtherBanksSHD_MB $B_{i t-1}+\beta_{4}$ MainBankSHD $D_{i t-1}+\beta_{5}$ OtherBanksSHD_MB $B_{i t-1}+\beta_{6}$ LiquidCost $_{i t}+\beta_{7}$ InfoAsym $_{i t}+\beta_{8} \log (\text { Age }+1)_{i t}+\beta_{9}$ MktShare ${ }_{i t}+\beta_{10}$ POS_ChgSale ${ }_{i t}+$

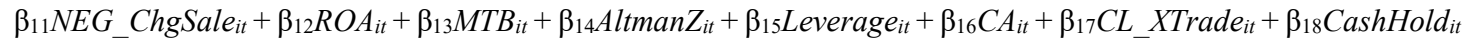
$+\beta$ INDUSTRY $+\beta$ YEAR $+\varepsilon_{i t}$,

TradeCredit $t_{i t}=\beta_{0}+\beta_{1} A Q_{i t-1}+\beta_{2} A Q_{i t-1} \times$ BankCrossSHD $D_{i t-1}+\beta_{3} A Q_{i t-1} \times$ OtherBanksSHD_BCSH $H_{i t-1}+\beta_{4}$ BankCrossSHD $_{i t-1}+\beta_{5}$ OtherBanksSHD_BCSH ${ }_{i t-1}+\beta_{6}$ LiquidCost $_{i t}+\beta_{7}$ InfoAsym $_{i t}+\beta_{8} \log (\text { Age }+1)_{i t}+\beta_{9}$ MktShare $i t+\beta_{10}$ POS_ChgSaleit +

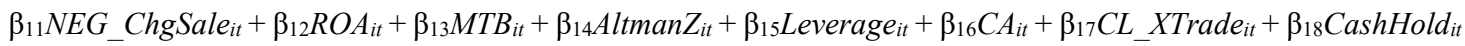
$+\beta$ INDUSTRY $+\beta$ YEAR $+\varepsilon_{i t}$, 
Table 6.

Accounting quality and trade credit: Firm-fixed effect

\begin{tabular}{|c|c|c|c|c|c|}
\hline Variable & (1) & (2) & (3) & (4) & $(5)$ \\
\hline \multirow[t]{2}{*}{ Intercept } & $-0.135 * * *$ & $-0.134 * * *$ & $-0.134 * * *$ & $-0.138 * * *$ & $-0.135 * * *$ \\
\hline & $(0.043)$ & $(0.043)$ & $(0.043)$ & $(0.043)$ & $(0.042)$ \\
\hline \multirow[t]{2}{*}{$A Q$} & 0.000 & $0.001 * *$ & $0.001 * *$ & $0.002 * *$ & $0.002 * *$ \\
\hline & $(0.000)$ & $(0.000)$ & $(0.000)$ & $(0.001)$ & $(0.001)$ \\
\hline$A Q \times$ & & $-0.003 * *$ & & & \\
\hline StableSH & & $(0.001)$ & & & \\
\hline$A Q \times$ & & & $-0.004 *$ & & \\
\hline CrossSH & & & $(0.002)$ & & \\
\hline$A Q \times$ & & & $-0.002 * *$ & & \\
\hline OtherStableSH & & & $(0.001)$ & & \\
\hline \multirow{2}{*}{ StableSH } & & -0.005 & & & \\
\hline & & $(0.007)$ & & & \\
\hline \multirow{2}{*}{ CrossSH } & & & -0.014 & & \\
\hline & & & $(0.010)$ & & \\
\hline \multirow{2}{*}{ OtherStableSH } & & & -0.002 & & \\
\hline & & & $(0.007)$ & & \\
\hline$A Q \times$ & & & & $-0.001 *$ & \\
\hline StableSHD & & & & $(0.001)$ & \\
\hline$A Q \times$ & & & & & $-0.001 *$ \\
\hline CrossSHD & & & & & $(0.001)$ \\
\hline$A Q \times$ & & & & & -0.001 \\
\hline OtherStableSHD & & & & & $(0.001)$ \\
\hline \multirow{2}{*}{ StableSHD } & & & & 0.002 & \\
\hline & & & & $(0.003)$ & \\
\hline \multirow{2}{*}{ CrossSHD } & & & & & -0.000 \\
\hline & & & & & $(0.002)$ \\
\hline \multirow{2}{*}{ OtherStableSHD } & & & & & 0.001 \\
\hline & & & & & $(0.002)$ \\
\hline Controls & included & included & included & included & included \\
\hline Firm FE & included & included & included & included & included \\
\hline Year FE & included & included & included & included & included \\
\hline Adjusted R-squared & 0.950 & 0.950 & 0.950 & 0.950 & 0.950 \\
\hline Observations & 27,794 & 27,794 & 27,794 & 27,794 & 27,794 \\
\hline
\end{tabular}

Robust standard errors clustered by firm are shown in parentheses. ${ }^{* * *},{ }^{* *}$, and ${ }^{*}$ indicate significance at 1 percent, 5 percent, and 10 percent levels, respectively (two-tailed). The dependent variable is TradeCredit. Variable definitions are provided in the Appendix. Columns (1), (2), (3), (4), and (5) show the results for equations (12), (13), (14), (15), and (16), respectively.

TradeCredit $_{i t}=\beta_{0}+\beta_{1} A Q_{i t-1}+\beta_{2}$ LiquidCost $_{i t}+\beta_{3} \operatorname{InfoAsym}_{i t}+\beta_{4} \log \left(\right.$ Asset $_{i t}+\beta_{5} \log (\text { Age }+1)_{i t}+\beta_{6}$ MktShare $_{i t}+$ $\beta_{7} P O S_{-}$ChgSaleit $+\beta_{8} N E G_{-}$ChgSaleit $+\beta_{9}$ ROA $_{i t}+\beta_{10} M T B_{i t}+\beta_{11}$ AltmanZ $_{i t}+\beta_{12}$ Leverage $_{i t}+\beta_{13}$ CA $_{i t}+$ $\beta_{14} C L \_$XTrade $_{i t}+\beta_{15}$ CashHold $_{i t}+\beta$ FIRM $+\beta$ YEAR $+\varepsilon_{i t}$,

TradeCredit $t_{i t}=\beta_{0}+\beta_{1} A Q_{i t-1}+\beta_{2}$ AQ $_{i t-1} \times$ StableSH $_{i t-1}+\beta_{3}$ StableSH $_{i t-1}+\beta_{4}$ LiquidCost $_{i t}+\beta_{5}$ InfoAsym $_{i t}+\beta_{6} \log ($ Age + $1)_{i t}+\beta_{7}$ MktShare $_{i t}+\beta_{8}$ POS ChgSale $i t+\beta_{9}$ NEG_ChgSaleit $+\beta_{10}$ ROA $_{i t}+\beta_{11}$ MTB $_{i t}+\beta_{12}$ AltmanZ $_{i t}+$ $\beta_{13}$ Leverage $_{i t}+\beta_{14}$ CAt $_{i t}+\beta_{15}$ CL_XTrade $i t+\beta_{16}$ CashHold $_{i t}+\beta$ FIRM $+\beta$ YEAR $+\varepsilon_{i t}$,

TradeCreditit $=\beta_{0}+\beta_{1} A Q_{i t-1}+\beta_{2} A Q_{i t-1} \times$ CrossSH $_{i t-1}+\beta_{3} A Q_{i t-1} \times$ OtherStableSH $_{i t-1}+\beta_{4}$ CrossSH $_{i t-1}+\beta_{5}$ OtherStableSH $_{i t-}$ 


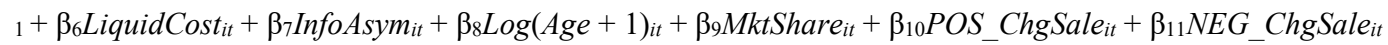
$+\beta_{12} R_{\text {ROA }}+\beta_{13}$ MTB $_{i t}+\beta_{14}$ AltmanZ $_{i t}+\beta_{15}$ Leverage $_{i t}+\beta_{16} C A_{i t}+\beta_{17} C L \_$XTrade $_{i t}+\beta_{18}$ CashHold $_{i t}+\beta$ FIRM $+\beta Y E A R+\varepsilon i t$.

TradeCredit ${ }_{i t}=\beta_{0}+\beta_{1} A Q_{i t-1}+\beta_{2} A Q_{i t-1} \times$ StableSHD $_{i t-1}+\beta_{3}$ StableSHD $_{i t-1}+\beta_{4}$ LiquidCost $_{i t}+\beta_{5}$ InfoAsym $_{i t}+\beta_{6} \log \left(\right.$ Age $_{\text {In }}$ $+1)_{i t}+\beta_{7}$ MktShare $_{i t}+\beta_{8}$ POS_ChgSale $i t+\beta_{9} N E G_{-}$ChgSale $i t+\beta_{10}$ ROA $_{i t}+\beta_{11}$ MTB $_{i t}+\beta_{12}$ AltmanZ $_{i t}+$ $\beta_{13}$ Leverage $_{i t}+\beta_{14}$ CA $_{i t}+\beta_{15} C L \_$XTrade $_{i t}+\beta_{16}$ CashHold $_{i t}+\beta$ FIRM $+\beta$ YEAR $+\varepsilon_{i t}$,

TradeCredit ${ }_{i t}=\beta_{0}+\beta_{1} A Q_{i t-1}+\beta_{2} A Q_{i t-1} \times$ CrossSHD $_{i t-1}+\beta_{3} A Q_{i t-1} \times$ OtherStableSHD $_{i t-1}+\beta_{4}$ CrossSHD $_{i t-1}+\beta_{5}$ OtherStableSHD $D_{i t-1}+\beta_{6}$ LiquidCost $_{i t}+\beta_{7}$ InfoAsym $_{i t}+\beta_{8} \log (\text { Age }+1)_{i t}+\beta_{9}$ MktShare $_{i t}+\beta_{10}$ POS_ChgSale $_{i t}+$ $\beta_{11} N_{E G}$ ChgSale $_{i t}+\beta_{12}$ ROA $_{i t}+\beta_{13}$ MTB $_{i t}+\beta_{14}$ Altman $_{i t}+\beta_{15}$ Leverage $_{i t}+\beta_{16}$ CA $_{i t}+\beta_{17}$ CL_XTrade ${ }_{i t}+$ $\beta_{18}$ CashHold $_{i t}+\beta$ FIRM $+\beta$ YEAR $+\varepsilon_{i t}$. 